\title{
Spatial analyses of thermokarst lakes and basins in Yedoma landscapes of the Lena Delta
}

\author{
A. Morgenstern ${ }^{1}$, G. Grosse ${ }^{2}$, F. Günther ${ }^{1}$, I. Fedorova ${ }^{3}$, and L. Schirrmeister ${ }^{1}$ \\ ${ }^{1}$ Alfred Wegener Institute for Polar and Marine Research, Telegrafenberg A43, 14473 Potsdam, Germany \\ ${ }^{2}$ Geophysical Institute, University of Alaska Fairbanks, 903 Koyukuk Drive, Fairbanks, AK 99775-7320, USA \\ ${ }^{3}$ Arctic and Antarctic Research Institute, Otto Schmidt Laboratory for Polar and Marine Research, Beringa st. 38, \\ 199397 St. Petersburg, Russia
}

Received: 19 April 2011 - Published in The Cryosphere Discuss.: 16 May 2011

Revised: 13 September 2011 - Accepted: 28 September 2011 - Published: 19 October 2011

\begin{abstract}
Distinctive periglacial landscapes have formed in late-Pleistocene ice-rich permafrost deposits (Ice Complex) of northern Yakutia, Siberia. Thermokarst lakes and thermokarst basins alternate with ice-rich Yedoma uplands. We investigate different thermokarst stages in Ice Complex deposits of the Lena River Delta using remote sensing and geoinformation techniques. The morphometry and spatial distribution of thermokarst lakes on Yedoma uplands, thermokarst lakes in basins, and thermokarst basins are analyzed, and possible dependence upon relief position and cryolithological context is considered. Of these thermokarst stages, developing thermokarst lakes on Yedoma uplands alter ice-rich permafrost the most, but occupy only $2.2 \%$ of the study area compared to $20.0 \%$ occupied by thermokarst basins. The future potential for developing large areas of thermokarst on Yedoma uplands is limited due to shrinking distances to degradational features and delta channels that foster lake drainage. Further thermokarst development in existing basins is restricted to underlying deposits that have already undergone thaw, compaction, and old carbon mobilization, and to deposits formed after initial lake drainage. Future thermokarst lake expansion is similarly limited in most of Siberia's Yedoma regions covering about $10^{6} \mathrm{~km}^{2}$, which has to be considered for water, energy, and carbon balances under warming climate scenarios.
\end{abstract}

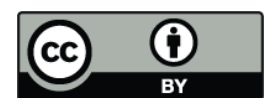

Correspondence to: A. Morgenstern (anne.morgenstern@awi.de)

\section{Introduction}

Climate warming in most northern high-latitude permafrost regions (ACIA, 2004) has resulted in widespread warming of permafrost, and also, in some cases, permafrost degradation during the last few decades (Romanovsky et al., 2010). Thawing of permafrost soils and sediments is often accompanied by the release of old organic carbon (Anisimov and Reneva, 2006; Zimov et al., 2006b; Schuur et al., 2008; Grosse et al., 2011a) and changes in water and land surface energy balances (Osterkamp et al., 2009), which may influence atmospheric processes via feedback mechanisms (Chapin et al., 2005; Walter et al., 2006; Schuur et al., 2009).

Thermokarst is one of the most obvious forms of permafrost degradation in arctic landscapes. Thermokarst is defined as the process by which characteristic landforms result from the thawing of ice-rich permafrost or the melting of massive ice (van Everdingen, 2005). During a phase of global warming about ten to twelve thousand years ago, thermokarst affected large areas in arctic lowlands with icerich permafrost (Romanovskii et al., 2000; Walter et al., 2007). In the late Pleistocene, such ice-rich deposits (Ice Complex) of the Yedoma Suite were deposited in northern Siberia (Sher et al., 1987; Schirrmeister et al., 2011b). Today, thermokarst lakes and basins alternate with ice-rich Yedoma uplands in this region. Thermokarst has important effects on the ecology, geomorphology, hydrology, and local climate of affected landscapes (Osterkamp et al., 2000; Grosse et al., 2011a). Various recent studies have investigated thermokarst lakes as sources of carbon release to the atmosphere ( $\mathrm{Zi}$ mov et al., 1997; Walter et al., 2006, 2007; Schuur et al., 2009; Zona et al., 2009; Karlsson et al., 2010) or as indicators of a changing water balance in permafrost regions by

Published by Copernicus Publications on behalf of the European Geosciences Union. 

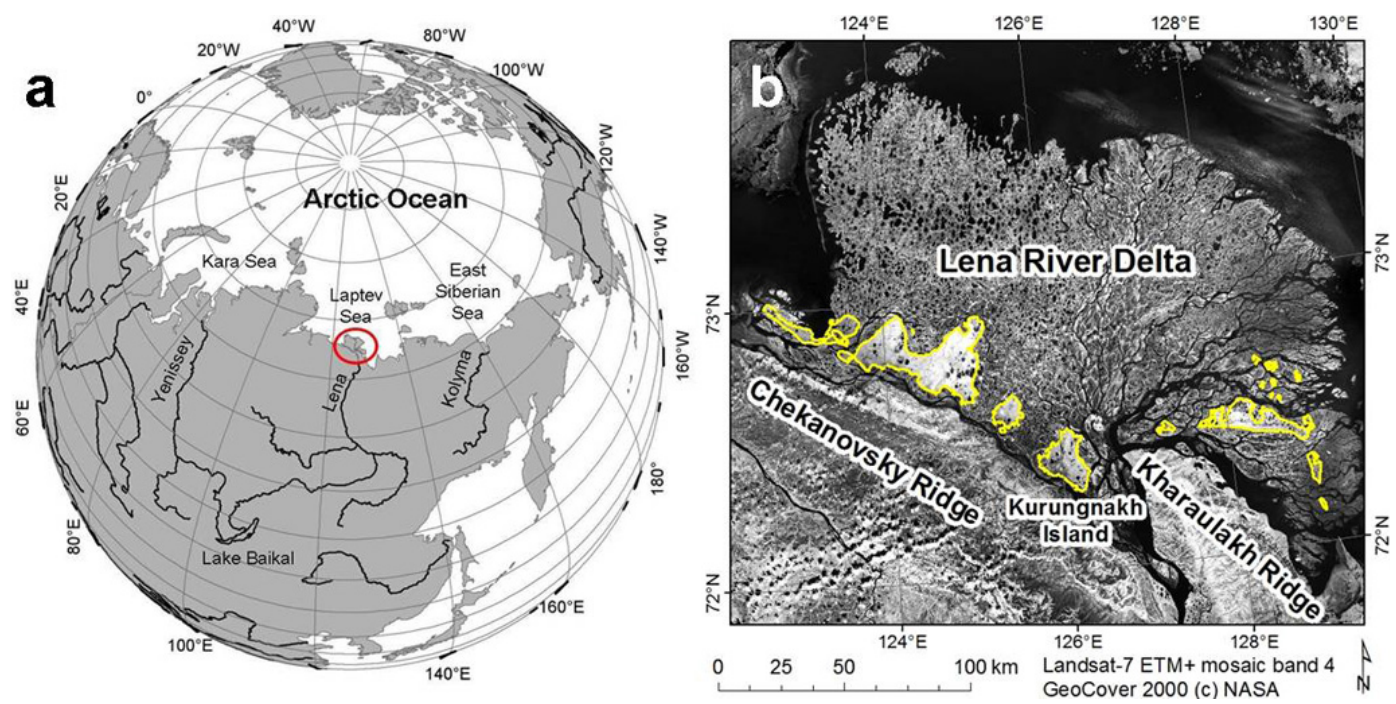

Fig. 1. Location of the study area in the Lena River Delta, North Siberia.

analyzing changes in lake area using remote-sensing methods (Payette et al., 2004; Smith et al., 2005; Riordan et al., 2006; Kravtsova and Bystrova, 2009). The highest methane emissions from arctic lakes are reported for lakes in Yedoma or Yedoma-like sediments (Walter et al., 2006). Drained thermokarst lake basins have been investigated on a broad scale using satellite remote sensing on the North Slope of Alaska (Frohn et al., 2005).

The classical works of Soloviev $(1959,1962)$ and Czudek and Demek (1970) describe the development of thermokarst in Ice Complex deposits in Central Yakutia (Siberia). In this region with a continental climate, thermokarst starts to develop under subaerial conditions. Only after initial ground subsidence does water accumulate in the evolving thermokarst basins that are termed "alasses" at a more developed stage. In the wet polygonal tundra of the north Siberian lowlands, evolving thermokarst in ice-rich deposits is represented by ponds and circular lakes that completely fill their basins. As these thermokarst lakes grow, they eventually coalesce with neighboring lakes or drain partially or completely. The remaining basins feature steep slopes, flat bottoms, and smaller remnant thermokarst lakes. Repeated cycles of permafrost degradation under thermokarst lakes and subsequent permafrost aggradation after full or partial lake drainage can lead to multiple cycles of secondary thermokarst within basins accompanied by modifications of initial basin-andlake morphometry and the growth of hydrostatic pingos in the basin (Katasonov, 1960; Romanovskii, 1961; Soloviev, 1962). Recent studies of modern thermokarst activity in Yedoma landscapes have focused on thermokarst lakes by detecting broad-scale changes in thermokarst lake area (e.g. Kravtsova and Bystrova, 2009). However, thus far they have not distinguished between thermokarst lakes on Yedoma uplands and thermokarst lakes in basins of older- generation thermokarst, and have not addressed these complex thermokarst basins. A broad review of hydrogeomorphological aspects of thermokarst lakes, drainage, and drained lake basins is provided by Grosse et al. (2011b).

To estimate future carbon release from Yedoma areas due to thermokarst it is necessary to assess the impact of thermokarst processes on the evolution of permafrost landscapes under climate scenarios that predict significant Arctic warming. In this study we provide a basis for quantifying potential thermokarst evolution in Siberian ice-rich permafrost by answering the question of where and to what extent thermokarst may develop in the study area, an area which comprises the third Lena River Delta terrace with its Ice Complex deposits. The specific objectives are: (1) to assess different stages in lake and basin development based on remote sensing and geoinformation techniques, (2) to analyze the spatial distribution of these lakes and basins, and elucidate any effects of relief position and cryolithological context, and (3) to deduce the potential extent of future thermokarst evolution in the study area.

\section{Study area and regional setting}

The north Siberian Lena River Delta $\left(73^{\circ} \mathrm{N} ; 126^{\circ} \mathrm{E}\right)$ is situated in the continuous permafrost and tundra zone. It features Ice Complex deposits on insular remnants of a late-Pleistocene accumulation plain in the foreland of the Chekanovsky and Kharaulakh ridges, which now form the third Lena Delta terrace (Grigoriev, 1993) (Fig. 1). These insular remnants of Ice Complex deposits will be termed islands in the following and named after the delta island they belong to. The stratigraphical composition of the third terrace can be divided into two late-Pleistocene main units and a Holocene unit (Schwamborn et al., 2002b; Schirrmeister et 


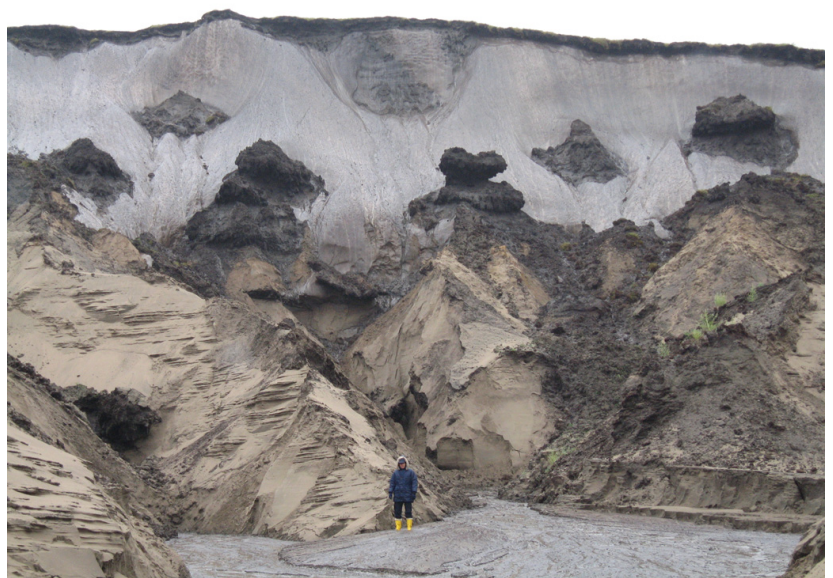

Fig. 2. Typical stratigraphical composition of the study area with lower fluvial sand unit, upper Ice Complex unit, and Holocene cover. Ice wedges in the Ice Complex appear in light grey colors. Person for scale (Photo by M. Ulrich, 26 August 2008).

al., 2003, 2011a; Wetterich et al., 2008) (Fig. 2). The lowest unit consists of fluvial, interbedded medium-to-fine-grained and silty sands deposited by a meandering paleo-Lena River during the early Weichselian period (between 100 and $50 \mathrm{ka}$ ). In some lower parts the sands include plant remains and alternate with peaty layers. The cryostructure of the sandy section is mostly massive with some small ice wedges. Gravimetric ice content is between 20 and $40 \mathrm{wt} \%$ and total organic carbon (TOC) content is between 1.0 and $5.4 \mathrm{wt} \%$. The upper Pleistocene unit is formed by polygenetic Ice Complex deposits that accumulated during the middle and late Weichselian (between 44.5 and $17 \mathrm{ka}$ ). It consists of peat, silty sand, and peaty paleosoil layers with a high gravimetric ice content (38 to $133 \mathrm{wt} \%$ ). The ground ice occurs as segregated ice in the form of ice bands, veins, and small ice lenses. Very large syngenetic ice wedges can be several meters wide and up to $20 \mathrm{~m}$ tall. TOC content exhibits a wide range in Ice Complex deposits (1.1 to $32.5 \mathrm{wt} \%$ ). The vertical position of the sharp boundary between the lower and upper units varies within the study area by up to several tens of meters, likely due to neotectonic block movements affecting the Lena Delta (Schwamborn et al., 2002b). In the western Lena Delta this boundary is found in the height range of 15$25 \mathrm{~m}$ above river level (a.r.l.), whereas in the eastern Lena Delta the boundary is located below the river level (Grigoriev, 1993). The Holocene unit is represented by deposits covering the Ice Complex and deposits of thermokarst depressions. Deposits of the Holocene cover exposed on top of the Ice Complex unit consist of brownish-black, cryoturbated silty sand with numerous small peat inclusions and are characterized by smaller ice wedges. Deposits of thermokarst depressions are composed of cryoturbated silty sands, numerous plant remains, and peat inclusions, and contain syn-

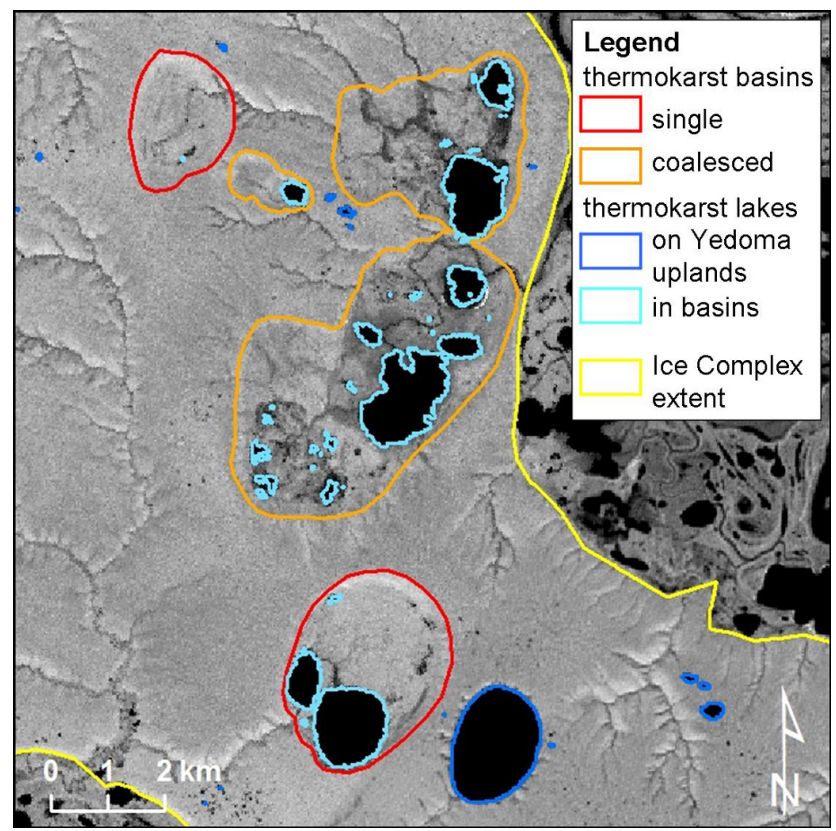

Fig. 3. Types of thermokarst features distinguished in this study.

genetic ice wedges about 3 to $5 \mathrm{~m}$ wide (Schirrmeister et al., 2003).

The modern outlines and surface patterns of the third terrace are the result of ca. 12000 years of permafrost degradation and of deltaic processes that have been ongoing since the mid-Holocene (Schwamborn et al., 2002b). Thermokarst processes have greatly influenced the landscapes in this region since the B $\varnothing$ lling-Allerød and during the early Holocene (Kaplina and Lozhkin, 1979; Romanovskii et al., 2000; Kaplina, 2009). Thermokarst lakes and basins are depressed into the flat Yedoma uplands of the study area. Individual and sometimes networked thermo-erosional channels drain the islands. Thermal erosion is fostered by high ice contents in the Yedoma and the high relief gradient of the third terrace; these small islands (a few tens of kilometers in diameter) are strongly dissected by delta channels and reach elevations of more than $60 \mathrm{~m}$ above the adjacent river level. Yedoma uplands are characterized by polygonal microrelief with small ponds. Thermokarst lakes can reach diameters of several kilometers. If their water table is below the surrounding Yedoma surface, their rims are often dissected by small thermo-erosional gullies (Fig. 3). Basin diameters range from several hundreds of meters for single forms to tens of kilometers for coalesced forms. Basin floors are mainly flat with ice-wedge polygons, polygon ponds, and thermokarst lakes that are mostly remnants of the initial large thermokarst lake that formed the basin. Pingos have formed in some of the basins, with heights up to $30 \mathrm{~m}$ above the basin surface and diameters of up to $150 \mathrm{~m}$ (Grigoriev, 1993). 
Within the study area, Kurungnakh Island $\left(72^{\circ} 23^{\prime} \mathrm{N}\right.$; $126^{\circ} 03^{\prime} \mathrm{E}$ ) (Fig. 1) serves as a key site for more detailed investigations. This island is the easternmost part of the tectonically uplifted western delta and has elevations of up to $55 \mathrm{~m}$ above sea level (a.s.l.).

\section{Data and methods}

\subsection{Remote-sensing data and processing}

A Landsat-7 ETM+ image mosaic of the Lena River Delta (Schneider et al., 2009) served as the basis for mapping the thermokarst lakes and basins within the extent of the Lena Delta Ice Complex. We defined this extent as all areas of the third geomorphological main terrace, excluding the bedrock outcrops of the Sardakh and Amerika-Khaya islands. We also excluded lakes and basins at the boundary of the Ice Complex whose original morphology has been directly influenced by fluvial-deltaic action. The manual mapping was done using a desktop Geographical Information System (GIS). The resulting vector layer was then modified using our own field knowledge and expert advice given by M. N. Grigoriev (personal communication, 2009).

The Landsat scenes covering the Ice Complex extent show a medium water level situation in summer (26 July 2001 in the western part, 27 July 2000 in the central and eastern part). An Ice Complex area of about $140 \mathrm{~km}^{2}$ affected by cloud cover was replaced by a subset of a Landsat scene from $5 \mathrm{Au}$ gust 2000 (path 130, row 9).

To extract all water bodies automatically, we applied a grey-level thresholding on band 5 of the Landsat data using the image processing software ENVI ${ }^{\mathrm{TM}}$ 4.6. In these midinfrared wavelengths water bodies are strong absorbers, easily distinguishable from other land cover types (Morgenstern et al., 2008a). All pixels with top-of-atmosphere reflectance values of 0 to 0.1 were defined as water. We manually removed all water pixels related to drainage channels, small streams, and river delta channels. The resulting data set was converted into vector polygons. Subsequent data processing and analyses were performed using the GIS software package ArcGIS $^{\mathrm{TM}} 9.3$ and its spatial data analysis toolbox. In the following all extracted water bodies are referred to as lakes for reasons of readability even though smaller water bodies are actually ponds.

Basins were manually digitized along their upper margins at the scale of 1:30000. The transition between Yedoma surface and basin slopes is visually clearly distinguishable in the Landsat data due to better drainage of slopes. Each basin was assigned to one of two categories: single basins are distinct basins formed by local thermokarst activity, whereas coalesced basins consist of at least two basins that have merged due to lateral lake expansion in the past. Basins that are located adjacent to each other and connected via narrow drainage channels but have retained their original morphom- etry were treated as separate features; each was assigned to the category single. Each lake was assigned a location attribute that had the value on Yedoma uplands or in basin (Fig. 3).

Mapping of all features was performed in the Universal Transverse Mercator (UTM) projection Zone $52^{\circ} \mathrm{N}$ with the geodetic datum WGS 1984 because this was the original projection of the Landsat mosaic. The study area has a large E-W extent of about $250 \mathrm{~km}$ and covers the $51^{\circ} \mathrm{N}$ and $52^{\circ} \mathrm{N}$ UTM zones. The UTM meridian is situated in the center of the Lena Delta and crosses Kurungnakh Island. To minimize distortion effects on morphometric calculations the data sets were separated along the UTM meridian into a western and an eastern part. The western part was re-projected to its original UTM Zone $51^{\circ} \mathrm{N}$. Kurungnakh Island and affiliated data sets were assigned completely to Zone $52^{\circ} \mathrm{N}$, because the larger areal percentage belongs to this zone.

\subsection{Morphometric analyses}

For all lakes and basins, morphometric variables including area, perimeter, circularity index, elongation index, orientation of major axis, and the coordinates of centroids were calculated (Table 1). The circularity index is a measure of how strongly an object's shape deviates from a perfect circle. Values approaching 0 indicate that an object has (a) an irregular or complex outline, (b) includes islands, or (c) is very elongated. A square has a value of 0.785 . The calculations of the elongation index (major axis/minor axis) and orientation of major axis refer to the axes of a best-approximated ellipse with an area equal to that of the object being analyzed.

Because the lakes were extracted from raster data and vectorized without smoothing, the $30 \mathrm{~m} \times 30 \mathrm{~m}$ spatial resolution of the Landsat data has to be taken into account for morphometric analyses. Star and Estes (1990) recommend using a conservative raster cell size, one sixteenth the size of the minimum mapping unit. Therefore, we set the minimum lake size for analyses of the shape metrics circularity index, elongation index, and orientation of main axis to be $14400 \mathrm{~m}^{2}$ (16 times $\left.30 \mathrm{~m} \times 30 \mathrm{~m}\right)$. The pixel-based outline of the lakes has a strong effect on the circularity index because it is based on area and perimeter. An object with a smooth outline will have a shorter perimeter than an object of the same area with a complex outline. In consequence, the pixel-based lake circularity cannot reach the value of 1 for a perfect circle and will always have lower values than digitized basins of the same shape. Thus, comparisons of circularity index between subpopulations of the data set are only legitimate among lakes, but not between lakes and basins, as the basins were manually digitized. The elongation index is therefore used as an additional measure and should give meaningful results because visual estimations of the basins (especially in the category single) reveal that they generally do not have complex outlines. 
Table 1. Overview of morphometric variables calculated for lakes and basins. Major and minor axes lengths and orientation of major axis for lakes are not shown here, but were calculated the same way as for basins.

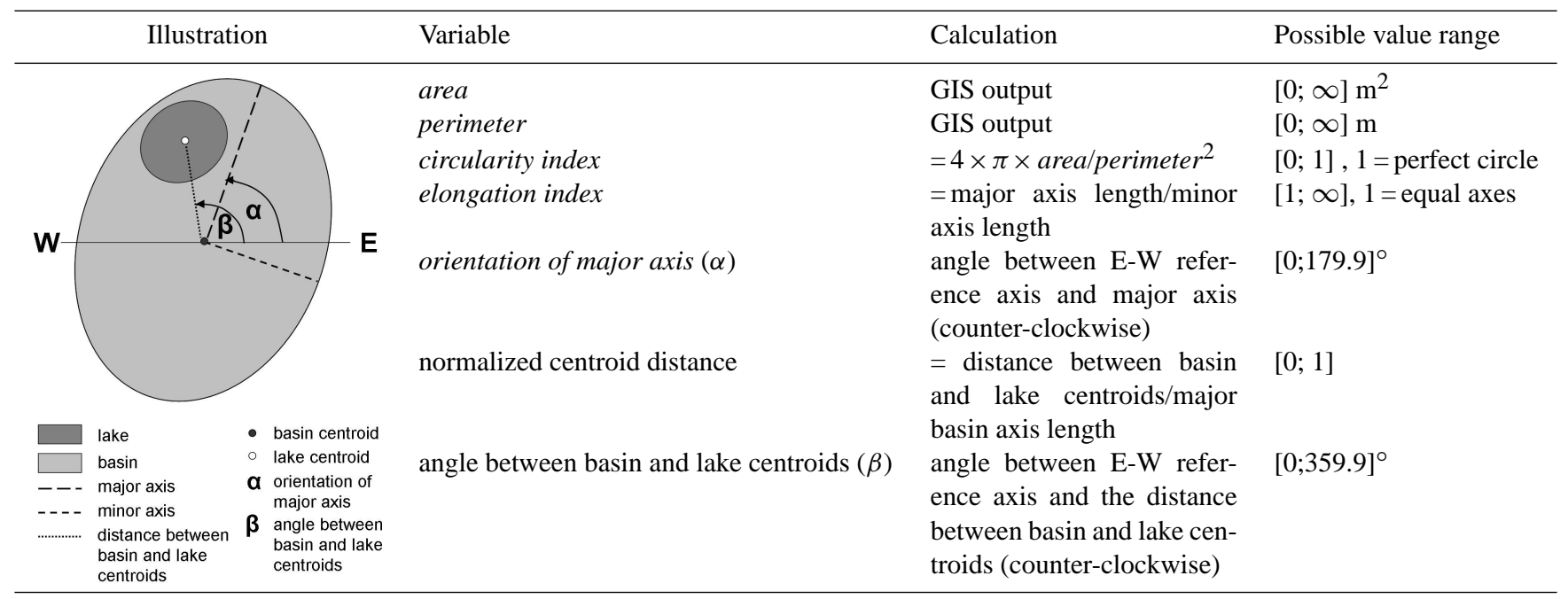

For each basin we determined the number of lakes per basin, the sum of lake area, and the percentage of lake area. The distance between basin centroid and lake centroid and the angle formed by moving counter-clockwise from the E$\mathrm{W}$ reference axis to the line between the centroids were calculated to assess the position of lakes within single basins (Table 1). Centroid distances were normalized by dividing the distance by the length of the major basin axis to allow comparison between basins of different sizes. In addition, pingos were mapped as point objects on the basis of Landsat and Corona satellite data and topographic maps. Distances and angles between pingos and basin centroids were calculated in the same way as for lakes in basins.

Statistical analyses of the resulting dataset were performed using the SPSS ${ }^{\mathrm{TM}} 16.0$ software. An explorative data analysis (EDA) and the Kolmogorov-Smirnov test revealed nonnormal distribution for all variables. Therefore, we used non-parametric tests for subsequent analyses. In order to test for morphometric differences between the subgroups lakes on Yedoma uplands versus lakes in basins and lakes on Yedoma uplands versus single basins, we applied the rankbased Mann-Whitney-U test.

\subsection{Relief analyses on Kurungnakh Island}

For Kurungnakh Island, a high-resolution Digital Elevation Model (DEM) based on an ALOS PRISM satellite image stereo triplet (acquisition date 21 September 2006) was available (Günther, 2009). The DEM has a horizontal resolution of $5 \mathrm{~m}$ and a vertical accuracy of $5.8 \mathrm{~m}$. For the rest of the study area, elevation information was derived from digitized 1:200 000 topographic maps. The spatial resolution of these maps is too coarse to extract terrain information in the de- tail needed for analyzing the thermokarst relief of the whole Lena Delta Ice Complex.

We used the high-resolution DEM to analyze the relief position of thermokarst features and, in particular, their position in relation to the two sedimentary units. According to Schirrmeister et al. (2003) and Wetterich et al. (2008) we assume that the average boundary between Ice Complex deposits and underlying fluvial sands lies between 15 and $20 \mathrm{~m}$ a.r.l. For calculation purposes in the GIS we set the height of the boundary to $17 \mathrm{~m}$ a.s.l. All lakes and basins whose floors are partially or completely below the $17 \mathrm{~m}$ contour line are considered to have their base in the fluvial sands of the lower stratigraphical unit.

Detailed field observations in combination with DEM analyses in eastern Kurungnakh Island revealed that in areas with a negligible slope of 0 to $2^{\circ}$ ice-wedge polygons occur, whereas in areas with slope $\geq 2^{\circ}$ usually no polygons exist, but hummocks are prevalent. We also interpret this threshold as the relief condition for thermokarst initiation, i.e. at slopes $\geq 2^{\circ}$ better drainage would prevent water accumulation and restrict lake formation. To calculate the area prone to potential new thermokarst lake development within the limits of the remaining Ice Complex on Kurungnakh Island, and assuming that new lakes would predominantly form on poorly drained, flat Yedoma upland surfaces, we subtracted all areas with a slope of $\geq 2^{\circ}$ and existing thermokarst lakes and basins from the area above the $17 \mathrm{~m}$ reference plane. The resulting binary raster was target-oriented filtered using a combination of the morphological Erode and Dilate filters of ENVI ${ }^{\mathrm{TM}} 4.8$ with a kernel size of $5 \times 5$ to correct for the influence of the systematic undulating surfaces of the DEM, which occurred mainly on the flat Yedoma uplands.

During a field campaign in summer 2008, the relief characteristics and lake bathymetries were investigated in detail 
Table 2. Area calculations for water bodies on the third Lena Delta terrace (except bedrock islands).

\begin{tabular}{lcccc}
\hline & $\begin{array}{c}\text { All lakes minimum } \\
\text { one pixel }\left(900 \mathrm{~m}^{2}\right)\end{array}$ & $\begin{array}{c}\text { Lakes on Yedoma } \\
\text { uplands }\end{array}$ & $\begin{array}{c}\text { Lakes in } \\
\text { basins }\end{array}$ & $\begin{array}{c}\text { All lakes } \\
\geq 14400 \mathrm{~m}^{2}\end{array}$ \\
\hline$N$ & 2327 & 1509 & 818 & 514 \\
Area $\left(\mathrm{km}^{2}\right)$ & 88.3 & 37.4 & 50.9 & 82.8 \\
Percentage of study area & 5.2 & 2.2 & 3.0 & 4.9 \\
\hline
\end{tabular}

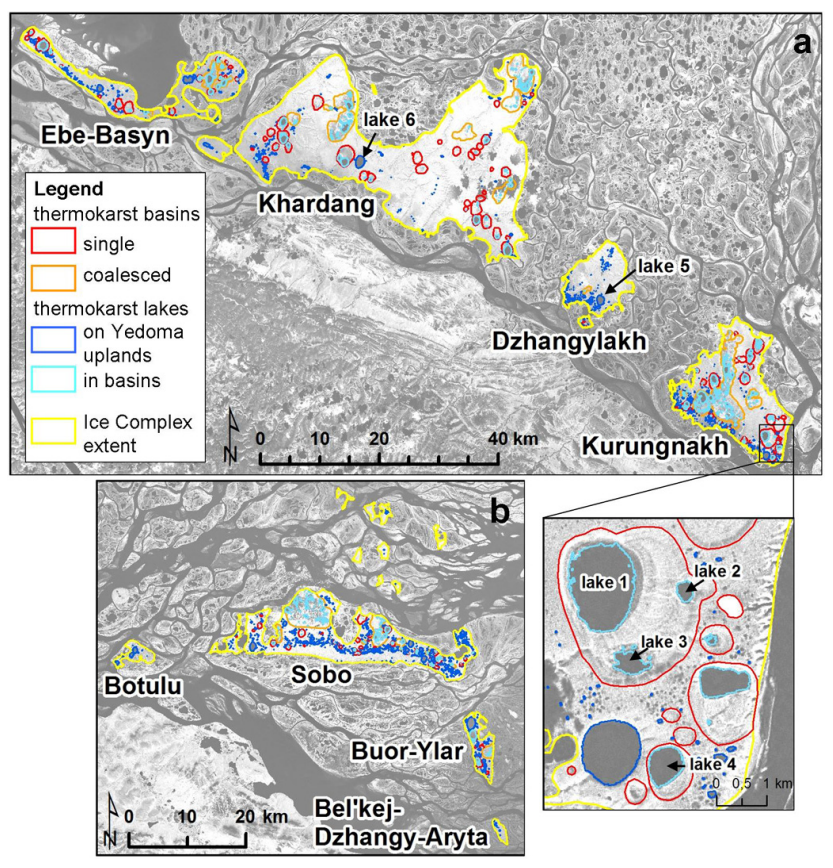

Fig. 4. Overview of study area with all thermokarst features investigated: (a) western part, (b) eastern part. Landsat-7 ETM+ mosaic, band 4, GeoCover 2000, (C) NASA.

in one thermokarst basin with three large lakes located in the south of Kurungnakh Island (Morgenstern et al., 2008b; Ulrich et al., 2010).

\section{Results}

\subsection{Area calculations and morphometric characteristics}

The study area, i.e. the mapped Ice Complex, covers an area of $1688.1 \mathrm{~km}^{2}$, which is $5.8 \%$ of the Lena Delta area $\left(29000 \mathrm{~km}^{2}\right)$ and $98.6 \%$ of the third terrace area $\left(1711.6 \mathrm{~km}^{2}\right)$; the remaining areas consist of exposed bedrock (Morgenstern et al., 2008a). We detected 2327 water bodies (minimum one pixel, $900 \mathrm{~m}^{2}$ ) with a total area of $88.3 \mathrm{~km}^{2}$ within the study area (Table 2). Thus, at a $30 \mathrm{~m}$ pixel resolution $5.2 \%$ of the Ice Complex extent is covered with open water. Of the total water body population, 1509 water bodies are situated on Yedoma uplands and 818 are

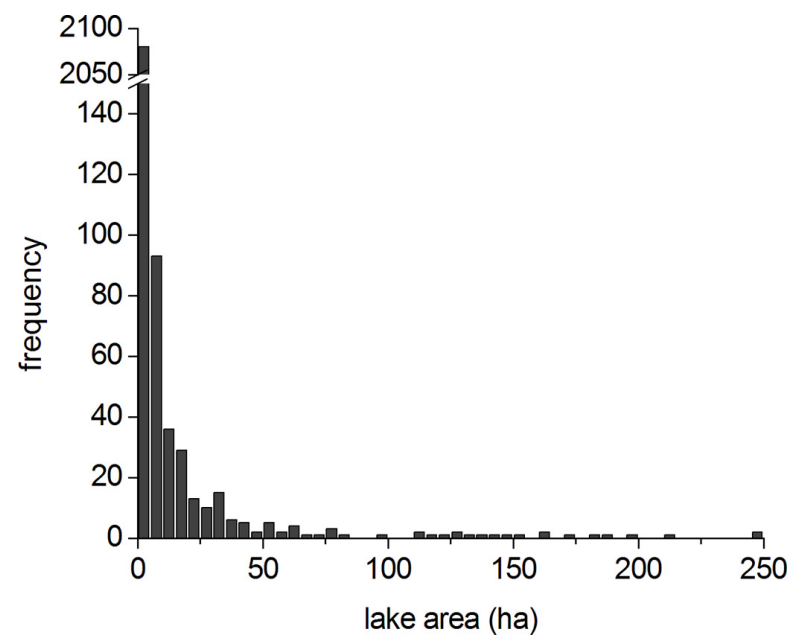

Fig. 5. Histogram of area of all water bodies in the study area $\left(1 \mathrm{ha}=10000 \mathrm{~m}^{2}\right)$.

in basins. Even though they are much more abundant, lakes on Yedoma uplands cover a smaller total area than lakes in basins (37.4 and $50.9 \mathrm{~km}^{2}$, respectively). Figure 4 shows the study area with all thermokarst lakes and basins mapped.

Thermokarst basins cover a total area of $337.7 \mathrm{~km}^{2}$ or $20.0 \%$ of the study area (Table 3 ). Of the 169 basins mapped, the majority $(n=144)$ was categorized as single. Single basins cover a much smaller areal extent, but show a higher lake area percentage than do coalesced basins $(20.2 \%$ and $11.7 \%$, respectively). Finally, $22.2 \%$ of the study area is affected by thermokarst. Lakes on Yedoma uplands account for a much lower proportion of total area than do thermokarst basins (2.2\% and $20.0 \%$, respectively).

Frequency distributions of area values for all water bodies in the study area show strong skewness towards lower values, because small water bodies are much more abundant than large lakes (Fig. 5). However, lakes $\geq 14400 \mathrm{~m}^{2}$ that are considered for morphometric analyses still cover $93.8 \%$ of the whole lake area, because even though their number is small (514 versus 2327 for the whole water body population) they account for most of the lake area. This is consistent with the specific patterns of the relationship between lake surface area and areal frequencies found in various Ice Complex regions (Grosse et al., 2008) or in more general patterns throughout other environments (Downing et al., 2006). 
Table 3. Area calculations for thermokarst basins on the third Lena Delta terrace (except bedrock islands).

\begin{tabular}{lccc}
\hline & All basins & Single basins & Coalesced basins \\
\hline$N$ & 169 & 144 & 25 \\
Area $\left(\mathrm{km}^{2}\right)$ & 337.7 & 133.0 & 204.7 \\
Percentage of study area & 20.0 & 7.9 & 12.1 \\
Total lake number & 818 & 263 & 555 \\
Sum of lake area $\left(\mathrm{km}^{2}\right)$ & 50.9 & 26.9 & 24.0 \\
Total lake area as a percentage of total basin area & 15.1 & 20.2 & 11.7 \\
\hline
\end{tabular}

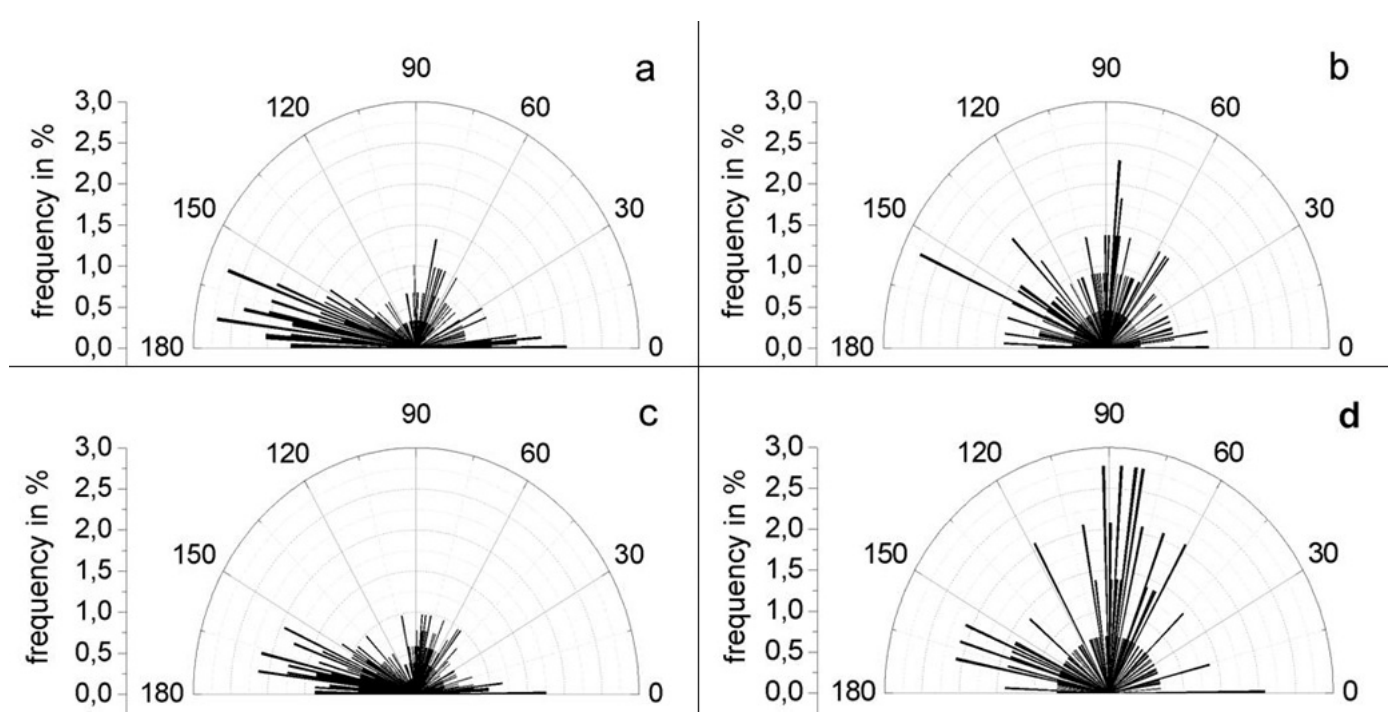

Fig. 6. Frequency distribution of major axis orientation for (a) lakes $\geq 14400 \mathrm{~m}^{2}$ on Yedoma uplands, (b) lakes $\geq 14400 \mathrm{~m}^{2}$ in basins, (c) all lakes $\geq 14400 \mathrm{~m}^{2}$, and (d) single basins. Intervals $=1^{\circ}, 0^{\circ}=$ East, $90^{\circ}=$ North, $180^{\circ}=$ West.

Lakes on Yedoma uplands $(n=296)$ differ significantly from lakes in basins $(n=218)$ in their morphometric characteristics except for the elongation index (Table 4). Lakes on Yedoma uplands are, on average, smaller than lakes in basins (median $=35000 \mathrm{~m}^{2}$ and $67900 \mathrm{~m}^{2}$, respectively) and have a smoother shoreline (Table 5). Frequency distributions of lake orientation on Yedoma uplands show a major peak in the WNW direction and a minor peak in the NNE direction (Fig. 6). Lakes in basins show a slightly different picture with a more pronounced NNE direction, but also two peaks directed to the WNW and NW.

Tests between lakes on Yedoma uplands $(n=296)$ and single basins $(n=144)$ reveal significant differences for all morphometric variables (Table 6). Lakes on Yedoma uplands are, on average, much smaller than single basins (by about one order of magnitude; the area median equals $35000 \mathrm{~m}^{2}$ and $362300 \mathrm{~m}^{2}$, respectively), and more elongated. Orientation shows the same major peaks for both groups, one in the NNE and one in the WNW direction, but with differing frequencies (Fig. 6). Lakes on Yedoma uplands have a much stronger prevailing orientation in the WNW direction; in contrast, single basins are more frequently oriented in the NNE direction. Table 5 shows a comparison of the morphometric characteristics between lakes on Yedoma uplands, lakes in basins, and single basins.

Frequency distributions of the major axis orientations for all lakes $\geq 14400 \mathrm{~m}^{2}$ show a major orientation peak in the WNW direction and a minor peak in the NNE direction (Fig. 6). In a previous study, all lakes $\geq 200000 \mathrm{~m}^{2}$ on the third Lena Delta terrace were found to exhibit a major NNE orientation (Morgenstern et al., 2008a). A selected distribution of major axis orientations for lakes with areas between $14400 \mathrm{~m}^{2}$ and $200000 \mathrm{~m}^{2}(n=425)$ shows a peak in the WNW direction. This indicates an approximately $90^{\circ}$ difference between the major orientation of smaller $\left(14400 \mathrm{~m}^{2}\right.$ to $\left.200000 \mathrm{~m}^{2}\right)$ and of larger $\left(\geq 200000 \mathrm{~m}^{2}\right)$ lakes. The frequency distributions of the major axis orientation of single basins show a major peak in the NNE and a minor peak in the WNW direction, opposite the orientation of all lakes $\geq 14400 \mathrm{~m}^{2}$.

Basins have a low lake area percentage (median $=3.9$ and 2.3, interquartile range $=19.0$ and 22.1 for all basins and for single basins, respectively). Correlation between basin area and lake area percentage was found to be slightly positive 
Table 4. Results of the rank-based Mann-Whitney-U test for morphometric differences between lakes on Yedoma uplands and lakes in basins. Significant differences between the two lake subgroups were found for area, circularity index, and orientation of major axis.

\begin{tabular}{lcccc}
\hline & Area & Circularity index & Elongation index & Orientation of major axis \\
\hline Mann-Whitney-U & 23916 & 23654 & 31059 & 26657 \\
$Z$ & -5.017 & -5.176 & -.724 & -3.369 \\
Asymptotic significance (two-sided) & $\mathbf{. 0 0 0}$ & $\mathbf{. 0 0 0}$ & .469 & $\mathbf{. 0 0 1}$ \\
\hline
\end{tabular}

Table 5. Comparison of morphometric characteristics of thermokarst lakes $\geq 14400 \mathrm{~m}^{2}$ and single basins. Area values for all lakes including lakes $<14400 \mathrm{~m}^{2}$ are shown in brackets.

\begin{tabular}{|c|c|c|c|c|c|}
\hline \multirow[b]{2}{*}{$N$} & \multicolumn{2}{|c|}{ Lakes on Yedoma uplands } & \multicolumn{2}{|c|}{ Lakes in basins } & \multirow{2}{*}{$\begin{array}{c}\text { Single basins } \\
144\end{array}$} \\
\hline & 296 & (1509) & 218 & $(818)$ & \\
\hline \multicolumn{6}{|l|}{ Area } \\
\hline Total $\left(\mathrm{km}^{2}\right)$ & 33.7 & $(37.4)$ & 49.1 & $(50.9)$ & 133.0 \\
\hline $\operatorname{Median}\left(\mathrm{m}^{2}\right)$ & 35000 & $(2700)$ & 67900 & (2700) & 362300 \\
\hline Interquartile range $\left(\mathrm{m}^{2}\right)$ & 65800 & (8100) & 210300 & $(16200)$ & 1096200 \\
\hline Minimum $\left(\mathrm{m}^{2}\right)$ & 14400 & $(900)$ & 14600 & $(900)$ & 20400 \\
\hline $\operatorname{Maximum}\left(\mathrm{m}^{2}\right)$ & 2482200 & $(2482200)$ & 2112300 & $(2112300)$ & 7706600 \\
\hline \multicolumn{6}{|l|}{ Circularity index } \\
\hline Median & 0.48 & & 0.41 & & 0.93 \\
\hline Interquartile range & 0.17 & & 0.21 & & 0.05 \\
\hline Minimum & 0.12 & & 0.07 & & 0.74 \\
\hline Maximum & 0.70 & & 0.70 & & 0.98 \\
\hline \multicolumn{6}{|l|}{ Elongation index } \\
\hline Median & 1.55 & & 1.58 & & 1.29 \\
\hline Interquartile range & 0.60 & & 0.82 & & 0.24 \\
\hline Minimum & 1.03 & & 1.04 & & 1.02 \\
\hline Maximum & 6.19 & & 8.07 & & 2.02 \\
\hline Outlines & \multicolumn{2}{|c|}{ smooth shorelines } & \multicolumn{2}{|c|}{ more complicated shorelines } & smooth, circular outlines \\
\hline Main orientation & \multicolumn{2}{|c|}{ WNW } & \multicolumn{2}{|c|}{ NNE } & NNE \\
\hline Depth & \multicolumn{2}{|c|}{$10 \mathrm{~m}$ and more } & \multicolumn{2}{|c|}{ up to $4 \mathrm{~m}$} & up to $35 \mathrm{~m}$ \\
\hline
\end{tabular}

Table 6. Results of the rank-based Mann-Whitney-U test for morphometric differences between lakes on Yedoma uplands and single basins. Significant differences between the two subgroups were found for all three morphometric variables.

\begin{tabular}{lrrr}
\hline & Area & $\begin{array}{r}\text { Elongation } \\
\text { index }\end{array}$ & $\begin{array}{r}\text { Orientation of } \\
\text { major axis }\end{array}$ \\
\hline Mann-Whitney-U & 4724 & 9823 & 17742 \\
$Z$ & -13.254 & -9.180 & -2.852 \\
Asymptotic signifi- & $\mathbf{. 0 0 0}$ & $\mathbf{. 0 0 0}$ & $\mathbf{. 0 0 4}$ \\
cance (two-sided) & & & \\
\hline
\end{tabular}

( $r=.453, p \leq .01$ for all basins and $r=.212, p \leq .01$ for single basins). Lakes in basins are not regularly situated in basin centers, but are shifted towards basin margins, mostly in northern and southern directions (Fig. 7).

Bathymetric data from six lakes in the study area suggest that lakes on Yedoma uplands are deeper than lakes in basins (Fig. 8). Lakes 1, 2, and 3 are situated in a $30 \mathrm{~m}$ deep thermokarst basin. Maximum recorded depth is $3.6 \mathrm{~m}$ for lake 1, $4.2 \mathrm{~m}$ for lake 2, and $4.0 \mathrm{~m}$ for lake 3 . Lake 4 is also located in a thermokarst basin, but it covers a large part of the basin floor. Its maximum recorded depth is $8.1 \mathrm{~m}$. Lakes 5 and 6 are situated on Yedoma uplands and reach depths of 12.5 and $9.0 \mathrm{~m}$, respectively (Pavlova and Dorozhkina, 2000). 
Table 7. Comparison of thermokarst features and permafrost characteristics between major islands of the study area.

\begin{tabular}{|c|c|c|c|c|c|c|c|c|c|}
\hline & & Ebe-Basyn & Khardang & Dzhangylakh & Kurungnakh & Botulu & Sobo & Buor-Ylar & $\begin{array}{c}\text { Bel'kej-Dzhangy- } \\
\text { Aryta }\end{array}$ \\
\hline \multirow[t]{3}{*}{ Island } & Area $\left(\mathrm{km}^{2}\right)$ & 160.7 & 826.7 & 93.9 & 259.5 & 14.5 & 262.1 & 32.2 & 5.6 \\
\hline & $\begin{array}{l}\text { Max. relief height } \\
(\mathrm{m} \text { a.s.1.) }\end{array}$ & 51 & 66 & 43 & 55 & 36 & 42 & 21 & 30 \\
\hline & $\begin{array}{l}\text { Max. Ice Complex } \\
\text { thickness }(\mathrm{m})^{\mathrm{b}}\end{array}$ & 33 & 48 & 16 & 38 & $36^{\mathrm{c}}$ & $42^{c}$ & $21^{\mathrm{c}}$ & $30^{\mathrm{c}}$ \\
\hline \multirow[t]{5}{*}{ Lakes } & $N$ & 205 & 375 & 227 & 549 & 14 & 841 & 92 & 11 \\
\hline & $\begin{array}{l}\left(N \geq 14400 \mathrm{~m}^{2}\right) \\
\text { Area }\end{array}$ & (57) & (93) & (23) & (116) & (5) & (185) & (27) & (4) \\
\hline & Total $\left(\mathrm{m}^{2}\right)$ & 13003200 & 22835900 & 3566900 & 19425600 & 674900 & 20781600 & 6111900 & 126000 \\
\hline & Median $\left(\mathrm{m}^{2}\right)$ & 4500 & 2700 & 1800 & 2700 & 8600 & 2400 & 4500 & 8100 \\
\hline & $\begin{array}{l}\text { Percentage of island } \\
\text { area }\end{array}$ & 8.1 & 2.8 & 3.8 & 7.5 & 4.7 & 7.9 & 19.0 & 2.3 \\
\hline \multirow[t]{9}{*}{ Basins } & $N$ & 25 & 46 & 5 & 44 & 0 & 42 & 7 & 0 \\
\hline & Area & & & & & & & & \\
\hline & Total $\left(\mathrm{m}^{2}\right)$ & 28098200 & 128906600 & 1811200 & 99235100 & - & 71386400 & 8425000 & - \\
\hline & Median $\left(\mathrm{m}^{2}\right)$ & 553100 & 1451100 & 351600 & 329900 & - & 323300 & 278900 & - \\
\hline & $\begin{array}{l}\text { Median of single } \\
\text { basins }\left(\mathrm{m}^{2}\right)\end{array}$ & 380000 & 1211300 & 224700 & 228700 & - & 248300 & 247000 & - \\
\hline & $\begin{array}{l}\text { Percentage of island } \\
\text { area }\end{array}$ & 17.5 & 15.6 & 1.9 & 38.2 & - & 27.2 & 26.2 & - \\
\hline & $\begin{array}{l}\text { Total lake area as } \\
\text { a percentage of total } \\
\text { basin area }\end{array}$ & 26.3 & 13.7 & 7.3 & 16.0 & - & 10.7 & 27.0 & - \\
\hline & $\begin{array}{l}\text { Median lake area per- } \\
\text { centage }\end{array}$ & 13.4 & 1.7 & 3.7 & 2.3 & - & 4.2 & 3.8 & - \\
\hline & Max. depth $(\mathrm{m})^{\mathrm{a}}$ & 15 & 30 & 15 & 35 & - & 10 & 10 & - \\
\hline \multirow{2}{*}{$\begin{array}{l}\text { Lakes on } \\
\text { Yedoma } \\
\text { uplands } \\
\text { and basins }\end{array}$} & Total area $\left(\mathrm{m}^{2}\right)$ & 33725400 & 134137200 & 5246700 & 102766700 & 674900 & 84509600 & 12266200 & 126000 \\
\hline & $\begin{array}{l}\text { Percentage of island } \\
\text { area }\end{array}$ & 21.0 & 16.2 & 5.6 & 39.6 & 4.7 & 32.2 & 38.1 & 2.3 \\
\hline
\end{tabular}

a Inferred from 1:200 000 topographical maps.

b Estimated from outcrop studies (Grigoriev, 1993) and maximum relief height.

c Values indicate the "visible" thickness above the river water level because the Ice Complex base is situated below the sea level here.
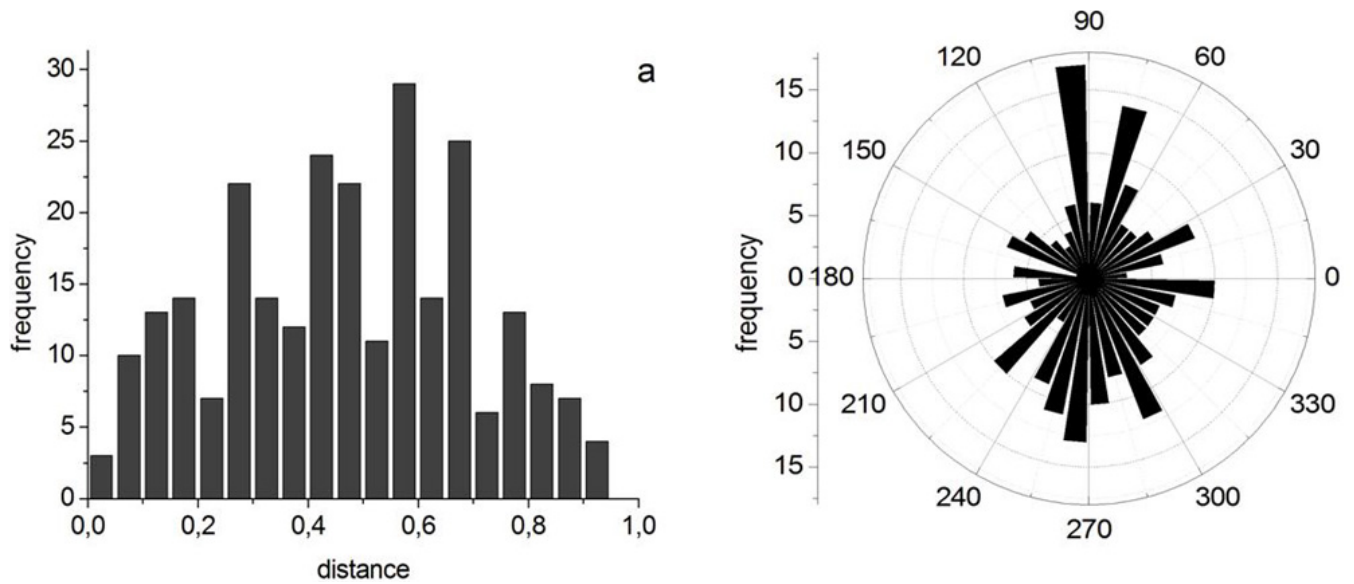

Fig. 7. Position of lakes within single basins: (a) frequency distribution of normalized distances between lake and basin centroids, (b) frequency distribution of angles $\left(\right.$ in $^{\circ}$ ) between basin and lake centroids. $0^{\circ}=$ East, $90^{\circ}=$ North, $180^{\circ}=$ West, $270^{\circ}=$ South . 


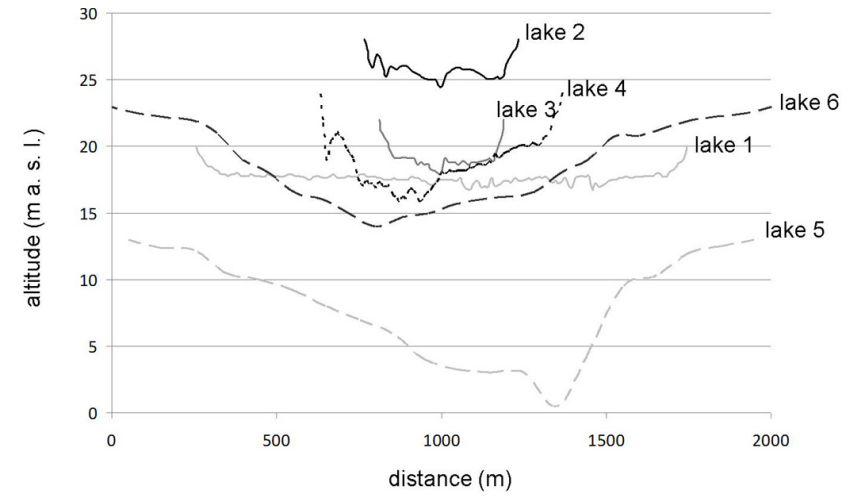

Fig. 8. Bathymetric profiles of lakes in relation to relief position. For lake locations see Fig. 4. Lake areas and profile directions are as follows: lake $1=1841400 \mathrm{~m}^{2}$, from $\mathrm{N}$ to $\mathrm{SE}$; lake $2=104400 \mathrm{~m}^{2}$, from $\mathrm{N}$ to $\mathrm{S}$; lake $3=221400 \mathrm{~m}^{2}$, from $\mathrm{N}$ to $\mathrm{S}$; lake $4=421200 \mathrm{~m}^{2}$, from $\mathrm{N}$ to $\mathrm{S}$; lake $5=1636790 \mathrm{~m}^{2}$, from $\mathrm{NW}$ to SE; lake $6=2460134 \mathrm{~m}^{2}$, from $\mathrm{N}$ to $\mathrm{S}$. Bathymetric data from lakes 5 and 6 from Pavlova and Dorozhkina (2000).

Table 7 compares the characteristics of permafrost relief, thermokarst lakes, and basins between major islands of the study area. Islands of the tectonically-uplifted western part of the study area show higher maximum relief heights, especially Khardang Island, which experienced separate block uplift (Grigoriev, 1993). Maximum Ice Complex thickness varies greatly between the islands, but shows similar ranges in the western and eastern parts of the study area. Maximum basin depths as inferred from topographic maps are lower in the eastern part, but do not seem proportional to maximum Ice Complex thickness. Khardang Island has a very low lake area percentage while featuring the largest basin sizes by far.

In the study area 34 pingos were mapped, the majority situated in coalesced thermokarst basins ( 24 versus ten in single basins). In single basins, pingos are situated at distances of several hundreds of meters from the basin centers $(\min =224 \mathrm{~m}, \max =598 \mathrm{~m}$; normalized distances: $\min =0.24$, $\max =0.57$ ), mostly in the NNE and SSW directions (Fig. 9).

\subsection{Relief analyses of Kurungnakh Island}

The mapped extent of the key study area on Kurungnakh Island is $259.5 \mathrm{~km}^{2}$. The total area of thermokarst (i.e. all thermokarst basins and lakes on Yedoma uplands) on $\mathrm{Ku}-$ rungnakh Island is $102.8 \mathrm{~km}^{2}$, or $39.6 \%$ of the key study area. Thermokarst lakes and basins that intersect or are situated below the $17 \mathrm{~m}$ isoline cover $71 \%$ of the total thermokarst area. This amounts to $73 \mathrm{~km}^{2}$, or $28.1 \%$ of the Kurungnakh Island area (Fig. 10). The surfaces of these thermokarst features (lake water level and basin bottoms) have subsided to the base of the Ice Complex deposits or lower. This areal calculation is very conservative because it does not take into account lakes and basins with surfaces

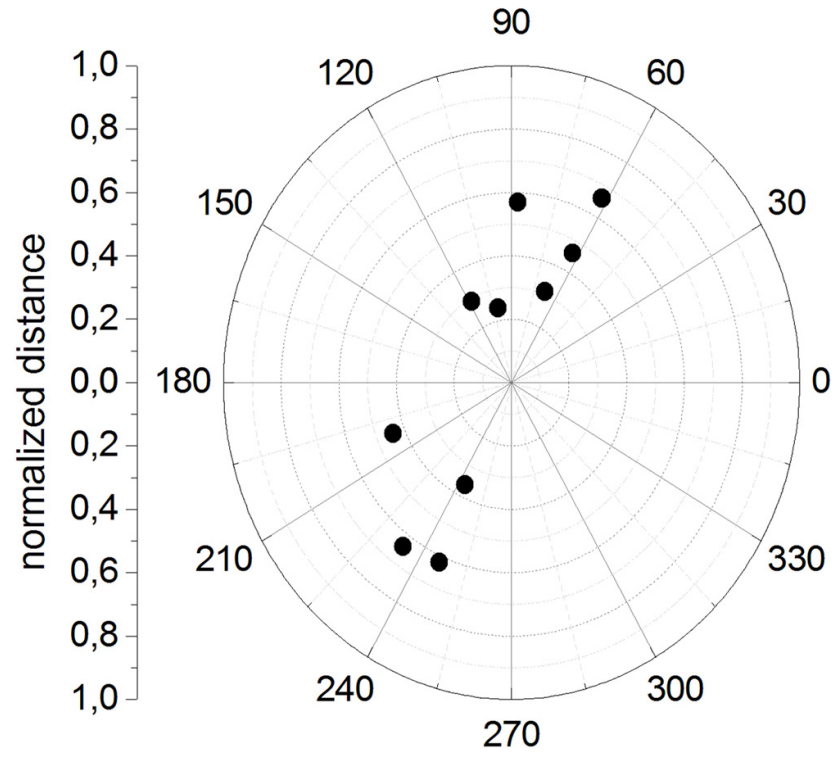

Fig. 9. Position of pingos within single basins. Normalized distances and angles (in ${ }^{\circ}$ ) were calculated between basin centroids and pingos. $0^{\circ}=$ East, $90^{\circ}=$ North, $180^{\circ}=$ West, $270^{\circ}=$ South .

above the $17 \mathrm{~m}$ contour line that should have formed taliks (bodies of unfrozen ground) that also reached the boundary between Ice Complex deposits and fluvial sands. This is illustrated in Fig. 11, which shows a profile line derived from the ALOS PRISM DEM that is situated above $17 \mathrm{~m}$ a.s.1. while the lake floors reach the $17 \mathrm{~m}$ level.

Based on the ALOS PRISM DEM, the deposits above the $17 \mathrm{~m}$ reference plane approximately represent the remaining Ice Complex deposits; the volume of these deposits was calculated to be $2.9 \mathrm{~km}^{3}$. The TOC reservoir of this volume amounts to $70 \mathrm{Mt}(=0.07 \mathrm{Pg})$ as calculated following the method described in Strauss et al. (2011), and corresponds to an average organic carbon inventory of $24 \mathrm{~kg} \mathrm{C} \mathrm{m}^{-3}$.

The area of Kurungnakh Island above $17 \mathrm{~m}$ a.s.l. with slopes of 0 to $2^{\circ}$ that is not included in the thermokarst features amounts to $87.4 \mathrm{~km}^{2}$ (Fig. 12). This means that only $33.7 \%$ of the area within the limits of Ice Complex deposits represents flat Yedoma uplands unaffected by thermokarst or thermal erosion where new thermokarst could potentially start to develop. However, we are aware that lateral thermokarst expansion of existing lakes close to slopes may result in reworking of Ice Complex deposits along these slopes as well.

\section{Discussion}

\subsection{Thermokarst extent in the study area}

Lakes cover $5.2 \%$ of the study area; this coverage is low compared to other arctic tundra regions like the western arctic coastal plain of Alaska with about $20 \%$ lake coverage 


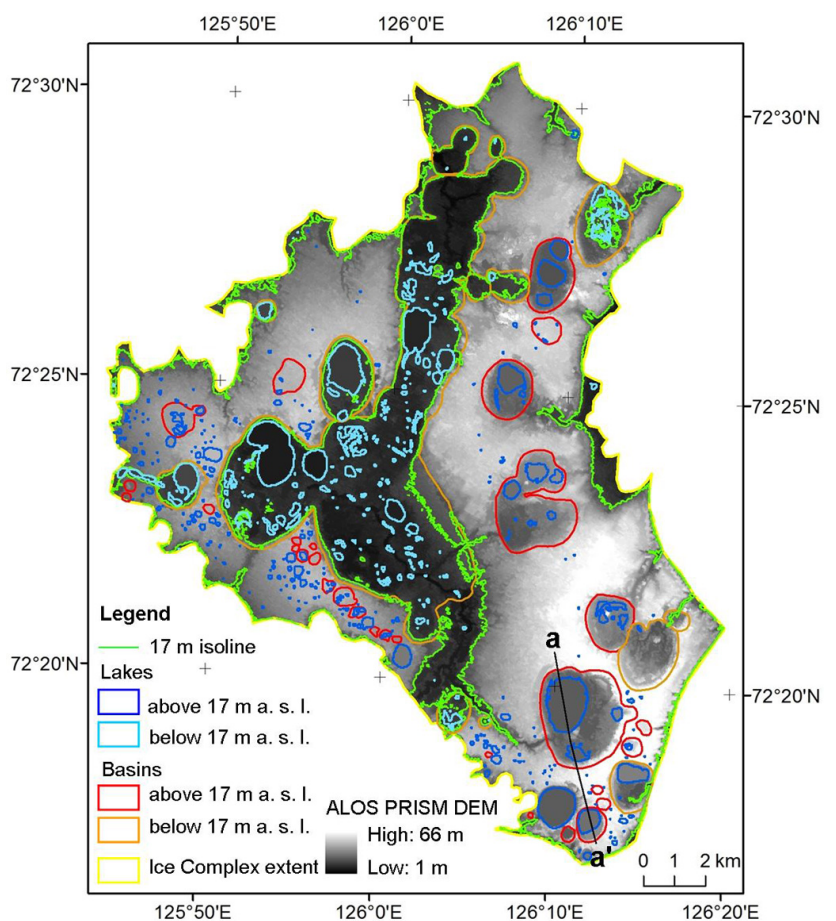

Fig. 10. DEM of Kurungnakh Island indicating the position of thermokarst features above and below the Ice Complex boundary at $17 \mathrm{~m}$ a.s.1. Of the total Kurungnakh Island area, $28.1 \%$ is covered by features under which the Ice Complex deposits should have already completely degraded. The line between $\mathbf{a}$ and $\mathbf{a}$ ' indicates a profile section across a Yedoma and thermokarst basin assemblage (see Fig. 11).

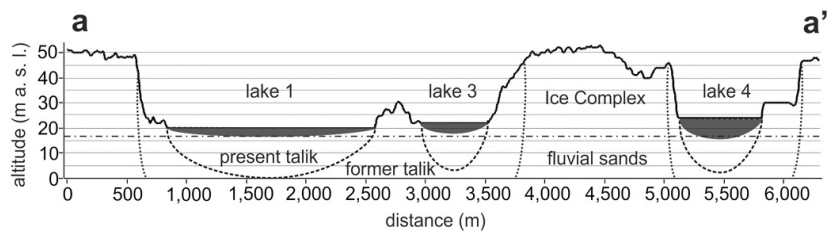

Fig. 11. Profile section across a Yedoma and thermokarst basin assemblage on Kurungnakh Island (for position see Fig. 10) showing topographic positions of investigated features. The thaw potential of thermokarst is much greater on Yedoma uplands than in basins. The profile line was derived from the ALOS PRISM DEM, the depths of lakes from bathymetric measurements, and the approximate position of the Ice Complex base from outcrop studies (Schirrmeister et al., 2003; Wetterich et al., 2008). Positions of taliks are hypothetical, based on modeling studies of similar environments in other regions (West and Plug, 2008).

(Hinkel et al., 2005) or the Tuktoyaktuk Peninsula in arctic Canada with $30 \%$ lake coverage (Côté and Burn, 2002). Within the Lena River Delta, the third terrace features the lowest lake area percentage (Morgenstern et al., 2008a). The Landsat resolution of $30 \mathrm{~m}$ per pixel did not allow small ponds to be detected. Grosse et al. (2008) showed that small

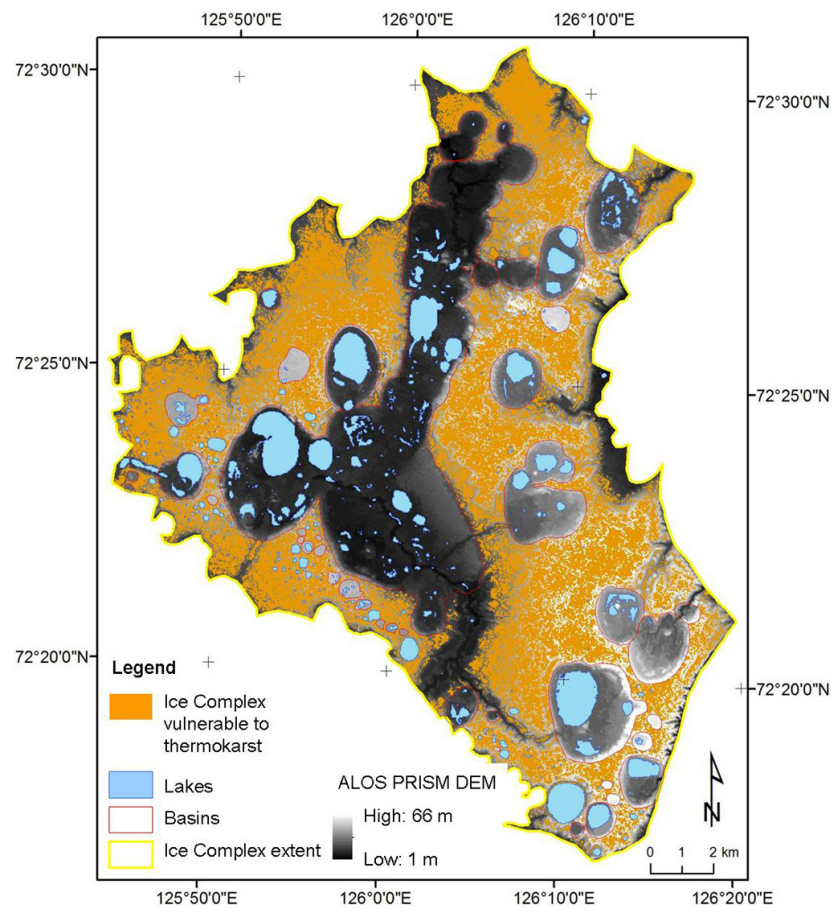

Fig. 12. Yedoma uplands of Kurungnakh Island unaffected by thermokarst or thermal erosion with slopes $<2^{\circ}$. This area $(33.7 \%$ of Kurungnakh Island) is vulnerable to future thermokarst.

ponds significantly contribute to the lake coverage of Ice Complex areas. For their OLE study site, which is part of the westernmost portion of our study area, they calculated $13.3 \%$ lake coverage including all standing water bodies of $\geq 30 \mathrm{~m}^{2}$. This is still a small percentage of the whole study area. An assessment of the area available for potential thermokarst evolution in Ice Complex deposits that is solely based on detecting thermokarst lakes by remotesensing methods would therefore deduce a high thermokarst potential for this study area. However, the total basin area mapped in our study area exceeds the total current lake area by a substantial factor of four, according to our calculations. This adds a high percentage to the area of Ice Complex degradation due to thermokarst, which is $22.2 \%$ of the study area. In Alaska, on the North Slope thermokarst lakes and drained basins cover a combined area of $46.1 \%$ (Frohn et al., 2005), and on the Barrow Peninsula $72 \%$ (Hinkel et al., 2003). The remaining $77.8 \%$ of our study area cannot be considered undisturbed Yedoma surfaces as thermal erosion also plays an important role in Ice Complex degradation. The results from Kurungnakh Island show that only $33.7 \%$ of the island area is undisturbed flat Yedoma surface. This is in the same range as results of previous remote-sensing-based studies that cover other portions of the Ice Complex accumulation plain in the Laptev Sea region. For the Bykovsky Peninsula east of the Lena Delta, Grosse et al. (2005) calculated the area affected by thermokarst and thermal erosion to be more 
than $50 \%$; for the area of Cape Mamontov Klyk west of the Lena Delta, Grosse et al. (2006) calculated the affected area to be $78 \%$.

\subsection{Areal constraints on thermokarst development}

Modern lakes on Yedoma uplands are, on average, much smaller than single basins (by about one order of magnitude). Taken together with the fact that total basin area exceeds total lake area, this suggests that thermokarst lakes have reached much greater sizes in the past. After drainage, basins can undergo expansion through lateral erosion mainly by secondary thermokarst lakes in the basins. The smoothness of single basin boundaries indicates that this process cannot account for substantial area increase after drainage of the initial lake, which suggests that the size of these basins is indeed largely a result of the first lake that formed. We therefore conclude that conditions for large-area thermokarst lake development were more suitable in the past. During the massive thermokarst development in this region about $12 \mathrm{ka}$ ago the coastline was situated hundreds of kilometers to the north of its present location (Bauch et al., 2001; Kaplina, 2009). The study area was not part of a river delta, but of a broad accumulation plain where Ice Complex deposits were distributed widely (Schirrmeister et al., 2011a). The terrain presumably was not as affected by fluvial erosion as it is nowadays in the delta context (Schwamborn et al., 2002b), and thermo-erosional gullies probably started to form simultaneously with the development of an increasing relief gradient between Yedoma uplands, thermokarst basins, and delta channels. Consequently, the area of thermokarst lake formation was little limited by the hydrological networks that forced growing lakes to drain; hence, large thermokarst lakes with diameters of several kilometers each were able to form.

In contrast, in the present situation small remnants of the former coherent Ice Complex plain have been elevated above a dynamic river delta environment, fostering the development of thermal erosion and the connection of Yedoma uplands to the hydrological network. The limiting effect of thermal erosion on the areal extent of thermokarst is also reflected in a lower lake area percentage in regions of higher relief energy, especially in the uplifted western part of the study area (Table 7). On Khardang Island, which has experienced an additional block uplift (Grigoriev, 1993), the discrepancy between the largest basins and the smallest lake area percentage suggests that there has been an abrupt change in thermokarst conditions, from large-scale to very limited, a change resulting from better drainage and thermal erosion.

Bosikov (1991) suggested that the lake area percentage of basins is an indicator of the evolutionary stage of thermokarst basins in central Yakutia. Younger thermokarst basins would have a higher lake area percentage than old basins. Assuming that smaller basins are younger, they should tend to have a higher lake area percentage than larger basins. In our study area we found an opposite correlation. However, sin- gle basins exhibit a higher lake area percentage compared to coalesced basins. This fact results from a better connection of coalesced basins to the hydrological network; these basins have often coalesced into broad valleys, which drained through thermo-erosional channels. The water accumulation that is required for renewed lake growth is, therefore, less probable in coalesced than in single basins. The total number of pingos in coalesced basins (24) is much higher than in single basins (10). The occurrence of pingos, therefore, might also indicate the evolutionary stage of thermokarst basins. However, it is beyond the scope of this study to further investigate this hypothesis. The more irregular shapes of lakes in basins compared to lakes on Yedoma uplands reflect the complex basin floor morphology with drainage channels, pingos, lake terraces, different areas of permafrost aggradation and subsidence, etc.

\subsection{Stratigraphical constraints on thermokarst development}

The low lake area percentage in basins indicates that if drainage of lakes on Yedoma uplands occurs, lake level falls to the elevation of the drainage sill. Further water supply to the basin cannot lead to further water level rise or to the infilling of the basin to its margins. Subsequent thermokarst evolution in the basins does not seem likely to result in the substantial further subsidence of the lake or basin floor that would be required for large secondary thermokarst lakes to develop in existing basins. This can be explained by the stratigraphy of the study area, in particular the relatively icepoor and thus thermokarst-resistant sand unit below the Ice Complex.

Figure 13 illustrates thermokarst evolution in the specific stratigraphical context of the study area. The maximum Ice Complex thickness observed at coastal bluffs is about $30 \mathrm{~m}$ (Grigoriev, 1993) and possibly reaches about $48 \mathrm{~m}$ on Khardang Island (Table 7). Basin depths of up to $30 \mathrm{~m}$ are common, so the majority of first-generation thermokarst lakes have already completely thawed the Ice Complex deposits within their basin footprint (stage 3 in Fig. 13).

In our study area, the sediments underlying the Ice Complex are fluvial sands with a gravimetric ice content of 20 to $40 \%$, which is too low to allow for continuing significant thermokarst subsidence below the Ice Complex base. Even if the floor of a first-generation thermokarst lake has not yet reached the Ice Complex base, its talik naturally will expand below it. A thermokarst lake a few meters deep will develop a talik several tens of meters deep in cold, ice-rich permafrost over several hundred to a few thousand years (Anisimova, 1962; Schwamborn et al., 2002a; West and Plug, 2008). Consequently, Ice Complex deposits underneath first-generation thermokarst lakes have undergone taberal development, including ice loss, organic carbon depletion, and compaction, resulting in a diagenetically altered, thawed sediment which may refreeze again after lake drainage. Portions of Ice 
1

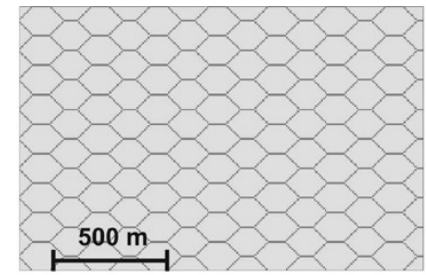

2

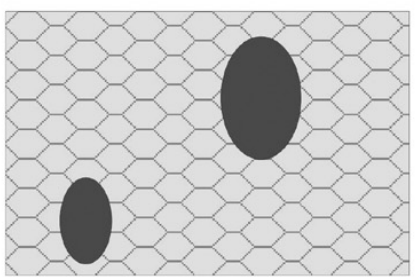

3

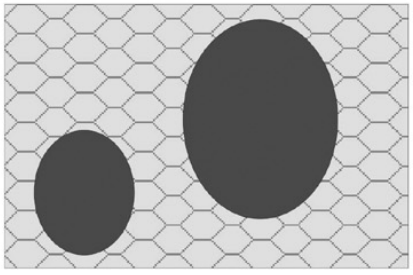

4

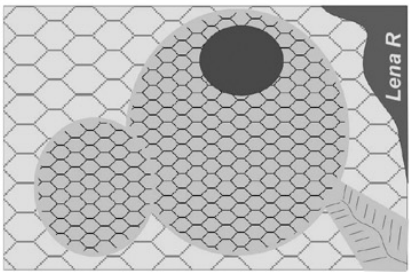

5

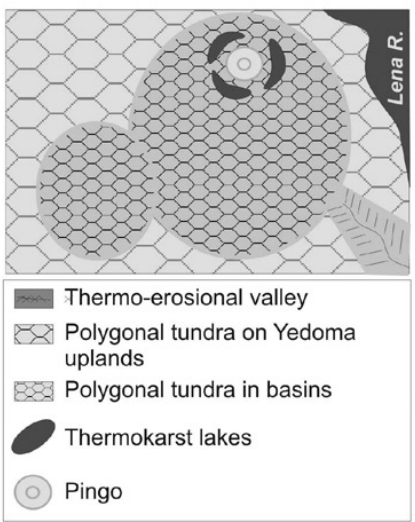

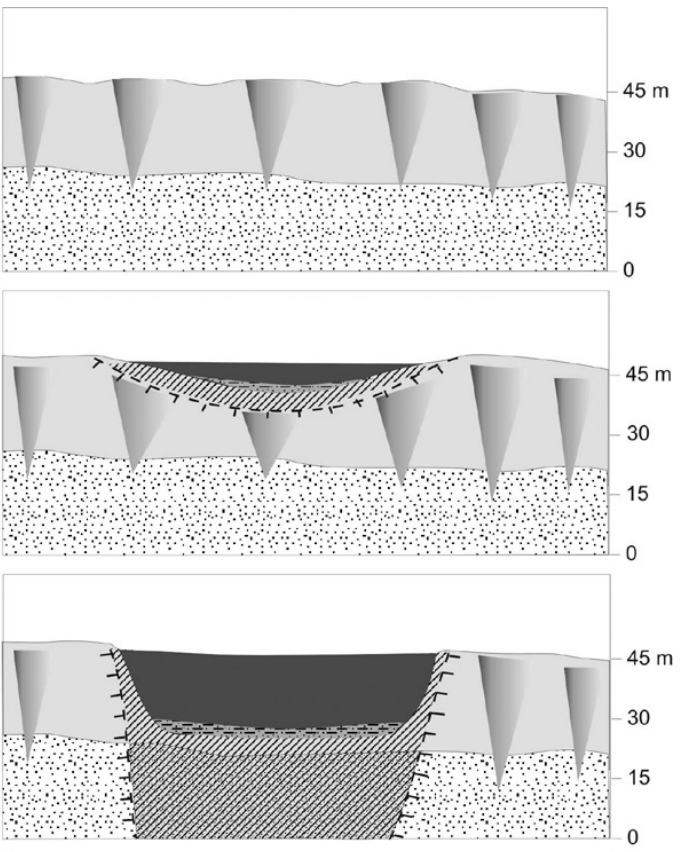
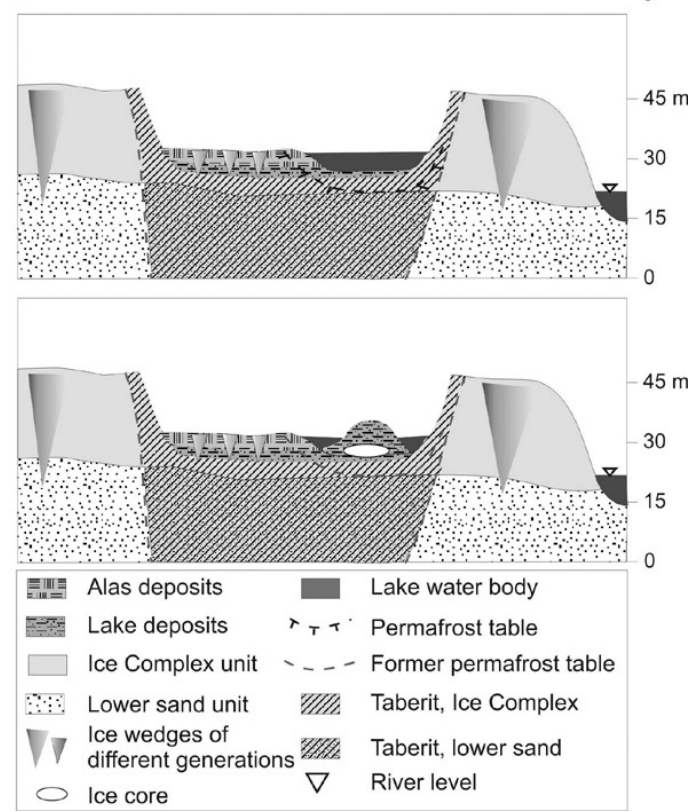

Fig. 13. Scheme of thermokarst development in Yedoma landscapes of the Lena River Delta in plane view (left) and cross section (right). 1: Flat, undisturbed Yedoma uplands with polygonal tundra. 2: Thermokarst lakes on Yedoma uplands - initial stage with lateral and vertical thermokarst development, lake sedimentation, talik in non-steady state. 3: Thermokarst lakes on Yedoma uplands - mature stage with lateral expansion only, lake sedimentation, talik fully developed. 4: Partially drained, coalesced thermokarst basin with remaining or secondgeneration thermokarst lake - partial refreezing of former talik, taberites, and lake sediments with ice aggradation and peat accumulation. 5: Partially drained coalesced thermokarst basin with pingo.

Complex deposits, including ground ice, are possibly conserved underneath smaller lake basins that drained at a stage corresponding to stage 2 in Fig. 13, before they reached full thermokarst maturity and developed a deep talik (Kaplina, 2009). However, only a small number of such basins exist in the study area as inferred from basin sizes.
After first-generation thermokarst lakes drained the taliks and basin deposits gradually refroze, permafrost formed accompanied by ground ice aggradation. The renewed ground ice content, however, does not reach the amount included in initial Ice Complex deposits which accumulated over several tens of thousands of years. Permafrost sediments that have 
developed in thermokarst basins can be divided into three main horizons with varying ground ice content (Kaplina, 2009; Wetterich et al., 2009) (stages 4 and 5 in Fig. 13). The lowest horizon represents the former Ice Complex sediments, which were thawed, compacted, partly deformed, and refrozen. These so-called taberites have a much lower ice content than did the original Ice Complex (between 20 to $40 \mathrm{wt} \%$ ), and can be several meters thick. Refrozen lake sediments overlaying the taberites have similar ground ice contents ( 20 to $40 \mathrm{wt} \%$ ). The top horizon (i.e. alas deposits) is formed by silt and peat layers with very high ground ice content similar to that of the Ice Complex (up to $200 \mathrm{wt} \%$ ), and can reach thicknesses of 5 to $7 \mathrm{~m}$. A system of ice veins and wedges penetrates these horizons of basin sediments, which are epigenetic in the taberal and lake sediments and syngenetic, due to peat accumulation, in the alas deposits (Kaplina, 2009; Wetterich et al., 2009). Favourable conditions for considerable second-generation thermokarst, therefore, are provided only in the top horizon; the lower two resemble the underlying fluvial sands in terms of low ground ice content.

The different potential for ground subsidence due to thermokarst is also supported by the different depths of lakes on Yedoma uplands versus lakes in basins (Fig. 8). While the former (lakes 5 and 6 ) reach depths of $12 \mathrm{~m}$, the latter (lakes 1 to 3) are no more than $4 \mathrm{~m}$ deep. Lake 4 illustrates an intermediate stage. It partly drained before thermokarst was fully developed. The exposed basin floor is situated at $30 \mathrm{~m}$ a.s.l., which is well above the Ice Complex base (Fig. 11). The remaining lake continued the thermokarst process and reached its present depth of $8 \mathrm{~m}$. The present lake floor is situated directly at the $17 \mathrm{~m}$ level, which we defined as the generalized Ice Complex base. In fact, the Ice Complex base should be situated a few meters lower here, because a layer of taberites necessarily exists underneath the lake bottoms. Its thickness depends on the original ice content of the Ice Complex; the lower the ice content, the thicker the taberal layer.

Figure 11 shows lake bottoms situated at the assumed Ice Complex base and lake surfaces and basin floors located only a few meters higher. This suggests that the taberal layer is only a few meters thick and the original ice content was very high. For the large thermokarst basin with lakes 1 to 3 , taberites have been calculated to be $2.3 \mathrm{~m}$ thick, assuming a total ice content of $90 \mathrm{vol} \%$ in the original Ice Complex (Ulrich et al., 2010). Soloviev (1962) also describes central Yakutian basin floors situated just above the Ice Complex base. Therefore, basin depths can be used as indicators of ice content and total thickness of Ice Complex deposits.

\subsection{Impact of future thermokarst development}

These findings emphasize that the effect of thermokarst development varies depending on whether it takes place on undisturbed plain surfaces or in existing basins of oldergeneration thermokarst. Newly developing thermokarst lakes on Yedoma uplands have a stronger transformative impact on permafrost sediments, landscape character, and environmental processes than thermokarst lakes in existing basins. Taliks forming underneath thermokarst lakes on Yedoma uplands enable the activation of physical and biochemical processes in the Ice Complex deposits, altering their structure and the composition of organic matter that had been conserved for thousands of years. The sediments in basins, however, have already been reworked and do not possess the characteristics of the very ice-rich permafrost of the surrounding Yedoma uplands. These differences between thermokarst on Yedoma uplands and thermokarst in basins also have implications for the carbon cycle. Walter et al. (2007) report that refrozen taberal Ice Complex deposits beneath drained Holocene thermokarst lakes contain $\sim 33 \%$ less carbon than those Ice Complex deposits that never thawed. Ice Complex on Yedoma uplands has a high ground ice content; therefore, it is very sensitive to potential thermokarst development in a warming climate. Thermokarst lakes developing on Yedoma uplands thus have a higher potential to mobilize older, and more labile, carbon than do second-generation thermokarst lakes in existing basins. At the same time the potential for the development of new thermokarst lakes, especially large lakes that are able to form extensive taliks before they drain, is very limited. A well-established connection of the basins to the drainage system also allows for the erosion of basin sediments. Taberites, lake sediments, and Holocene peat horizons together with ground ice that aggraded during refreezing can be removed from the basin floor, thus eliminating the basis for future thermokarst development. In this case, the organic matter of the basin sediments is transported to the fluvial system.

On Kurungnakh Island, at least $71 \%$ of all thermokarst lakes and basins have subsided to the Ice Complex base. Here, the Ice Complex deposits have thawed completely and have been exposed to biogeochemical processes such as the decomposition of old organic matter. If we assume that fullydeveloped taliks have existed underneath most of the remaining $29 \%$ of thermokarst lakes and basins, thermokarst has completely degraded Ice Complex deposits in up to $39.6 \%$ of the area of Kurungnakh Island. Areas outside existing thermokarst lakes and basins above the Ice Complex base with slopes of up to $2^{\circ}$ are available for the initiation of new thermokarst lakes because these areas allow ponding of water and ground subsidence. The areas with slopes of more than $2^{\circ}$ can also be affected by thermokarst, mainly by lateral growth of existing thermokarst lakes. In some cases ponding of water can also occur on upper slopes of Yedoma uplands. However, extensive thermokarst activity is not possible here, because lateral growth will lead to drainage when the lake reaches the lower parts of the slope. Many of the steeper slopes $\left(5\right.$ to $\left.20^{\circ}\right)$ surround large thermokarst lakes or belong to thermo-erosional valleys that cut across the surface of $\mathrm{Ku}-$ rungnakh Island, indicating that lateral sediment transport and mass wasting processes are also important contributors 
to the degradation of Ice Complex deposits. Key processes are thermal abrasion of lake shores and thermal erosion in retrogressive valleys or gullies. Mobilization, transport, and transformation of organic matter differ between in situ thawing and ground subsidence in local thermokarst lakes and the lateral dynamics involving slope processes and flowing water. It will thus be of interest in future work to investigate the extent to which the remaining Ice Complex is degraded by newly developing thermokarst, or by thermal abrasion due to the expansion of thermokarst lakes in existing basins, or by thermal erosion.

The implications of significantly reduced thermokarst potential in large parts of the study area are also highly relevant for most other Yedoma landscapes in Siberia, which are estimated to occupy an area of $10^{6} \mathrm{~km}^{2}$ (Zimov et al., 2006a). Environmental changes at the transition between Pleistocene and Holocene led to extensive thermokarst activity in Siberian Ice Complex deposits (Kaplina, 2009). The percentage of thermokarst affected terrain as well as the morphology of thermokarst lakes and basins varies between different Yedoma regions. Precise calculations of Yedoma and thermokarst area percentages are rare, but old thermokarst basins generally exist in nearly all Yedoma regions and restrict future thermokarst lake expansion. In the Kolyma lowlands, for example, Kaplina et al. (1986) report different degrees of Yedoma dissection by thermokarst basins from weak $(<25 \%)$ to very high $(>75 \%)$. In a subset of this area, Veremeeva and Gubin (2009) calculated that $65 \%$ are covered by thermokarst basins and only $26 \%$ represent Yedoma uplands. For the Yedoma region of the Bykovsky Peninsula, Grosse et al. (2005) found that about $53 \%$ of the area is affected by thermokarst. For the Lena-Anabar lowland, which is similar in geological composition to the Lena Delta study area with Ice Complex deposits underlain by fluvial sands, about $49 \%$ of the area is covered with thermokarst landforms (Grosse et al., 2006). Kaplina (2009) points out two types of Yedoma territories in north Yakutian lowlands, where thermokarst has no potential to develop. The first type corresponds to the situation in our study area representing drained Yedoma massifs and remnants where water accumulation is impeded. The second type are areas, where coalesced thermokarst basins form extensive alas plains underneath which the former Ice Complex almost completely underwent taberal reworking. This shows that investigations of modern and possible future thermokarst lake development in Siberian Yedoma regions in the context of changes in landscape, hydrology, climate, carbon cycle, etc. always have to consider the history of former thermokarst evolution and permafrost degradation.

\subsection{Oriented thermokarst development}

The lateral growth of thermokarst lakes and the spatial development of second-generation thermokarst in existing basins did not proceed uniformly, as can be seen from morphometric and orientation analyses. Even though lakes and basins in the study area are not as elongated as the oriented lakes of the second Lena Delta terrace (Morgenstern et al., 2008a), the descriptive statistics of circularity and elongation indicate a general deviation from round and regular forms. Smaller lakes (14400 to $200000 \mathrm{~m}^{2}$ ) are oriented mainly in the WNW direction whereas larger lakes $\left(\geq 200000 \mathrm{~m}^{2}\right)$ and single basins have major orientation peaks to the NNE. Several hypotheses can be proposed to explain this $90^{\circ}$ shift in orientation from smaller to larger forms. First, if it is true that smaller thermokarst lakes have not existed as long as larger lakes and single basins, the external orienting forces may have changed their direction by $90^{\circ}$ at some time during the Holocene. Second, the strength of the orienting forces may have changed with growing lake size. Third, smaller lakes may be dominated by different orientationdriving forces than are larger lakes. Despite several decades of research, there is still a debate about which factors control thermokarst lake orientation in areas where lake orientation does not follow underlying relief structures. On the North American Arctic Coastal Plain, preferential erosion of the lake shores at right angles to prevailing summer wind directions due to wind-driven currents and wave activity has been proposed and agrees well with current main wind directions (e.g. Carson and Hussey, 1962; Côté and Burn, 2002; Hinkel et al., 2005); however, authors investigating orientation and directed evolution of thermokarst lakes and basins in Siberian Ice Complex deposits discuss solar insolation (e.g. Soloviev, 1962; Boytsov, 1965; Ulrich et al., 2010) and erosion due to wave activity in the direction of prevailing summer winds (e.g. Kuznetsova, 1961). The first of our three hypotheses would rule out solar insolation as the main factor for lake orientation. A possible explanation could be a change in major summer wind direction during the Holocene. Under our second hypothesis an important effect of solar insolation is also implausible. However, if main summer wind direction remained stable, a change in its effect from wave-induced erosion (abrasion) in the wind direction to the establishment of wind-driven currents at right angles to the main wind direction or vice versa might be possible. Our third hypothesis implies that in smaller lakes wind has a stronger effect on orientation than does solar insolation, while in larger lakes and in basins the effect of solar insolation dominates that of wind effects. This is physically not plausible, as wind effects should intensify with growing lake area.

A change detection study for all lakes $\geq 10000 \mathrm{~m}^{2}$ on $\mathrm{Ku}-$ rungnakh Island revealed the directional growth of lakes in the NNW direction during the investigated time period of about 40 years (Günther, 2009). Following the solar radiation hypothesis, the NNE (SSW-facing) slopes of the lakes and basins should receive maximum energy shortly after noon and therefore be preferentially eroded. The results of modeling solar radiation rates for a thermokarst basin on Kurungnakh Island showed the highest values for south-facing basin slopes. Rates for west-facing slopes exceeded rates for eastfacing slopes (Ulrich et al., 2010). Solar insolation as the 
single orienting factor is thus only acceptable if a summer cloud-cover regime with consistently higher cloudiness in the afternoon were to be observed on Kurungnakh Island. Wind data from the meteorological station on Stolb Island near Kurungnakh Island $\left(72.4^{\circ} \mathrm{E} 126.5^{\circ} \mathrm{N}\right.$, data from 1955-1991) show pronounced southern wind directions for the whole observation period and three peaks for the period of positive temperatures, one from the $\mathrm{S}$, one from the ESE, and one from the NNW (Morgenstern et al., 2008a). This would support the hypothesis of orientation due to prevailing winds in the direction of major axes for the lakes of Kurungnakh Island over the last 40 years.

Lakes in basins are not situated in the centers of the basins, but are shifted mainly towards northern and southern margins (Fig. 7), indicating that asymmetrical basin profiles result from directional basin evolution. Thermokarst lakes are often deeper at the sides of active thermokarst development (Romanovskii, 1961). After partial drainage, residual lakes in basins remain at the sides of recent thermokarst activity. If thermokarst development proceeded unidirectionally over the whole study area, as has been observed for Kurungnakh Island over the last 40 years, lakes in basins should be situated predominantly in one direction only from the basin center. The bi-directionally clustered distribution of lakes in basins therefore does not support hypotheses of unidirectional factors such as solar insolation and prevailing summer winds in the direction of the main axes. It is interesting to note that the position of pingos in single basins is similar to the position of lakes in basins; pingos are also shifted in northern and southern directions from the basin centers (Fig. 9). However, the low number of pingos in single basins in the study area does not permit using pingo position to derive robust conclusions about oriented thermokarst development.

The inconsistencies of lake and basin orientation patterns in the study area over space and time, as described above, do not allow the cause of oriented thermokarst development in the Yedoma landscapes of the Lena River Delta to be clearly elucidated at present.

\section{Conclusions}

Large parts of the study area are affected by thermokarst, and total thermokarst basin area exceeds total thermokarst lake area by a factor of four. Three developmental stages of thermokarst complexity have been distinguished in this study: (1) lakes on Yedoma uplands, (2) single basins with residual and second-generation lakes, and (3) coalesced basins with residual and second-generation lakes. The morphometric characteristics of lakes on Yedoma uplands differ significantly from those of lakes in basins or single basins, reflecting different evolutionary conditions. However, the differences between the two lake types are not clear-cut and do not allow for automatically classifying lakes on Yedoma uplands and lakes in basins based on morphometric indicators in a GIS. Thermokarst lakes and single basins show oriented morphometries, but the factors and processes responsible for oriented thermokarst development in the study area remain unclear. Conditions more suitable to the development of large-area thermokarst in the Ice Complex deposits of our study area have existed in the past; such development will be further limited in area and depth in the future. The proximity of newly-developing thermokarst to existing degradational features like thermokarst basins and thermo-erosional valleys as well as to delta channels reduces the potential for considerable thermokarst activity on Yedoma uplands before drainage occurs. On Kurungnakh Island, $33.7 \%$ of the total area is vulnerable to future thermokarst on Yedoma uplands. Further thermokarst processes in existing basins are limited due to the underlying ice-poor fluvial sands and, in the case of basins where permafrost has aggraded during the Holocene, due to the thin layers of ice-rich alas sediments and peat horizons. No old organic carbon will be directly mobilized from these areas. Developing thermokarst lakes on undisturbed Yedoma uplands have the highest impact on the alteration of Ice Complex deposits and Yedoma landscapes. However, past thermokarst activity and erosion have severely diminished original Yedoma surfaces, not only in the study area, but in Siberian Yedoma regions in general, so future thermokarst lake expansion in these landscapes may be considerably restricted. Therefore, it is necessary to differentiate between the various developmental stages of thermokarst and landscape units in order to assess the degradation of very icerich permafrost due to thermokarst, for example to quantify organic carbon inventories and the potential for future carbon fluxes.

Acknowledgements. We thank M. N. Grigoriev for his advice on enhancing the map of the Ice Complex in the Lena Delta, as well as for discussions of the broader context of the study. We also thank U. Herzschuh for discussions of statistical methods used to assess lake and basin morphologies and J. Strauss for calculating the total organic carbon inventory of the Kurungnakh Island Ice Complex. We greatly appreciate the efforts of all German and Russian colleagues in organizing and supporting the expeditions to the Lena Delta, and especially the field assistance of M. Ulrich, S. Rößler, and P. Ivlev. ALOS PRISM data used for DEM compilation were kindly provided by JAXA and ESA through the LEDAM project (awarded by ESA ADEN, PI H. Lantuit, ID 3616). A. Morgenstern was supported by the German National Academic Foundation and the Christiane Nüsslein-Volhard Foundation. G. Grosse was supported by NASA grant NNX08AJ37G and NSF OPP grant \#0732735. C. O'Connor (University of Alaska, Fairbanks) provided careful language revision and constructive comments. The constructive reviews of L. Smith and one anonymous reviewer as well as the personal discussion with T. N. Kaplina helped to enhance the manuscript.

Edited by: D. Riseborough 


\section{References}

ACIA: Impacts of a warming Arctic - Arctic Climate Impact Assessment, Cambridge, Cambridge University Press, 146 pp., 2004.

Anisimov, O. A. and Reneva, S. A.: Permafrost and changing climate: The Russian perspective, Ambio, 35, 169-175, 2006.

Anisimova, N. P.: Geothermal investigations in taliks underneath several water bodies and streams in central Yakutia, in: Permafrost and accompanying phenomena on the territory of the Yakutian ASSR, USSR Academy of Sciences, Moscow, 89-95, 1962 (in Russian).

Bauch, H. A., Mueller-Lupp, T., Taldenkova, E., Spielhagen, R. F., Kassens, H., Grootes, P. M., Thiede, J., Heinemeier, J., and Petryashov, V. V.: Chronology of the Holocene transgression at the North Siberian margin, Global Planet. Change, 31, 125-139, 2001.

Bosikov, N. P.: Evolution of Central Yakutian alasses, Permafrost Institute Yakutsk, Siberian Branch, USSR Academy of Sciences, Yakutsk, 128 p., 1991 (in Russian).

Boytsov, M. N.: Morphological evolution of thaw lake basins, in: Anthropogenic period in the Arctic and Subarctic, 143, edited by: NEDRA, Research Institute Geology of the Arctic, Moscow, Russia, 327-340, 1965 (in Russian).

Carson, C. E. and Hussey, K. M.: The oriented lakes of Arctic Alaska, J. Geol., 70, 417-439, 1962.

Chapin, F., Sturm, M., Serreze, M., McFadden, J., Key, J. R., Lloyd, A. H., McGuire, A. D., Rupp, T. S., Lynch, A. H., Schimel, J. P., Beringer, J., Chapman, W. L., Epstein, H. E., Euskirchen, E. S., Hinzman, L. D., Jia, G., Ping, C.-L., Tape, K. D., Thompson, C. D. C., Walker, D. A., and Welker, J. M.: Role of landsurface changes in Arctic summer warming, Science, 310, 657660, doi:10.1126/science.1117368, 2005.

Côté, M. M. and Burn, C. R.: The oriented lakes of Tuktoyaktuk Peninsula, western arctic coast, Canada: A GIS-based analysis, Permafrost Periglac., 13, 61-70, doi:10.1002/ppp.407, 2002.

Czudek, T. and Demek, J.: Thermokarst in Siberia and its influence on the development of lowland relief, Quat. Res., 1, 103-120, 1970.

Downing, J. A., Prairie, Y. T., Cole, J. J., Duarte, C. M., Tranvik, L. J., Striegl, R. G., McDowell, W. H., Kortelainen, P., Caraco, N. F., Melack, J. M., and Middelburg, J. J.: The global abundance and size distribution of lakes, ponds, and impoundments, Limnol. Oceanogr., 51, 2388-2397, 2006.

Frohn, R. C., Hinkel, K. M., and Eisner, W. R.: Satellite remote sensing classification of thaw lakes and drained thaw lake basins on the North Slope of Alaska, Remote Sens. Environ., 97, 116126, doi:10.1016/j.rse.2005.04.022, 2005.

Grigoriev, M. N.: Cryomorphogenesis of the Lena River mouth area, Siberian Branch, USSR Academy of Sciences, Yakutsk, 176 p., 1993 (in Russian).

Grosse, G., Schirrmeister, L., Kunitsky, V. V., and Hubberten, H.$\mathrm{W}$.: The use of CORONA images in remote sensing of periglacial geomorphology: An illustration from the NE Siberian coast, Permafrost Periglac., 16, 163-172, doi:10.1002/ppp.509, 2005.

Grosse, G., Schirrmeister, L., and Malthus, T. J.: Application of Landsat-7 satellite data and a DEM for the quantification of thermokarst-affected terrain types in the periglacial Lena-Anabar coastal lowland, Polar Res., 25, 51-67, 2006.

Grosse, G., Romanovsky, V., Walter, K., Morgenstern, A., Lantuit,
H., and Zimov, S.: Distribution of thermokarst lakes and ponds at three Yedoma sites in Siberia, in: Proceedings of the 9th International Conference on Permafrost, Fairbanks, Alaska, 29 June-3 July 2008, edited by: Kane, D. L. and Hinkel, K. M., Institute of Northern Engineering, University of Alaska Fairbanks, 551-556, 2008.

Grosse, G., Harden, J., Turetsky, M., McGuire, A. D., Camill, P., Tarnocai, C., Frolking, S., Schuur, E. A. G., Jorgenson, T., Marchenko, S., Romanovsky. V., Wickland, K. P., French, N., Waldrop, M., Bourgeau-Chavez, L., and Striegl, R. G.: Vulnerability of high latitude soil carbon in North America to disturbance, J. Geophys. Res., 116, G00K06, doi:10.1029/2010JG001507, 2011a.

Grosse, G., Jones, B., and Arp, C.: Thermokarst lakes, drainage, and drained basins, Elsevier, Treatise on Geomorphology, in press, $2011 b$.

Günther, F.: Investigation of thermokarst evolution in the southern Lena Delta using multitemporal remote sensing and field data, unpublished diploma thesis, Tech. Univ. of Dresden, Dresden, Germany, 96 pp., 2009 (in German).

Hinkel, K. M., Eisner, W. R., Bockheim, J. G., Nelson, F. E., Peterson, K. M., and Dai, X. Y.: Spatial extent, age, and carbon stocks in drained thaw lake basins on the Barrow Peninsula, Alaska, Arct. Antarct. Alp. Res., 35, 291-300, 2003.

Hinkel, K. M., Frohn, R. C., Nelson, F. E., Eisner, W. R., and Beck, R. A.: Morphometric and spatial analysis of thaw lakes and drained thaw lake basins in the western Arctic Coastal Plain, Alaska, Permafrost Periglac., 16, 327-341, doi:10.1002/ppp.532, 2005.

Kaplina, T. N.: Alas complex of Northern Yakutia, Kriosfera Zemli (Earth Cryosphere), 13, 3-17, 2009 (in Russian).

Kaplina, T. N. and Lozhkin, A. V.: Age of alas deposits of the Yakutian coastal plain, Geologiya (Geology), 2, USSR Academy of Sciences, 69-76, 1979 (in Russian).

Kaplina, T. N., Kostalyndina, N. K., and Leibman, M. O.: Relief analysis of the Kolyma lowlands for cryolithological mapping, in: Formation of frozen ground and prognosis of cryogenic processes, Nauka, Moscow, 51-60, 1986 (in Russian).

Karlsson, J., Christensen, T. R., Crill, P., Förster, J., Hammarlund, D., Jackowicz-Korczynski, M., Kokfelt, U., Roehm, C., and Rosén, P.: Quantifying the relative importance of lake emissions in the carbon budget of a subarctic catchment, J. Geophys. Res., 115, G03006, doi:10.1029/2010JG001305, 2010.

Katasonov, E. M.: On the deposits of the thermokarst lakes "alasses" in the Yana maritime lowlands, Geologiya i Geofisika (Geology and Geophysics), 2, Siberian Branch, USSR Academy of Sciences, 103-112, 1960 (in Russian).

Kravtsova, V. I. and Bystrova, A. G.: Changes in thermokarst lake sizes in different regions of Russia for the last 30 years, Kriosfera Zemli (Earth Cryosphere), 13, 16-26, 2009 (in Russian).

Kuznetsova, T. P.: Oriented lakes of the Yano-Indigirka coastal lowland, in: Questions on the Geography of Yakutia, USSR Academy of Sciences, Yakutsk, 68-70, 1961 (in Russian).

Morgenstern, A., Grosse, G., and Schirrmeister, L.: Genetic, morphological, and statistical characterization of lakes in the permafrost-dominated Lena Delta, in: Proceedings of the 9th International Conference on Permafrost, Fairbanks, Alaska, 29 June-3 July 2008, edited by: Kane, D. L. and Hinkel, K. M., Institute of Northern Engineering, University of Alaska Fairbanks, 
1239-1244, 2008a.

Morgenstern, A., Ulrich, M., Guenther, F., Roessler, S., and Lantuit, H.: Combining ALOS data and field investigations for the reconstruction of thermokarst evolution in the North Siberian Lena Delta, in: Proceedings of the Second ALOS PI 2008 Symposium (CD-ROM), ESA SP-664, ESA Communication Production Office, ESA, Noordwijk, Netherlands, http://hdl.handle.net/10013/ epic.31924, 2008b.

Osterkamp, T. E., Viereck, L., Shur, Y., Jorgenson, M. T., Racine, C., Doyle, A., and Boone, R. D.: Observations of thermokarst and its impact on boreal forests in Alaska, U.S.A., Arct. Antarct. Alp. Res., 32, 303-315, 2000.

Osterkamp, T. E., Jorgenson, M. T., Schuur, E. A. G., Shur, Y. L., Kanevskiy, M. Z., Vogel, J. G., and Tumskoy, V. E.: Physical and ecological changes associated with warming permafrost and thermokarst in Interior Alaska, Permafrost Periglac., 20, 235256, doi:10.1002/ppp.656, 2009.

Pavlova, E. Yu. and Dorozhkina, M.: Geomorphological studies in the western and central sectors of the Lena Delta, in: Expeditions in Siberia in 1999, edited by: Rachold, V., Reports on Polar Research, vol. 354, Alfred Wegener Institute for Polar and Marine Research, Bremerhaven, 2000.

Payette, S., Delwaide, A., Caccianiga, M., and Beauchemin, M.: Accelerated thawing of subarctic peatland permafrost over the last 50 years, Geophys. Res. Lett., 31, L18208, doi:10.1029/2004GL020358, 2004.

Riordan, B., Verbyla, D., and McGuire, A. D.: Shrinking ponds in subarctic Alaska based on 1950-2002 remotely sensed images, J. Geophys. Res., 111, G04002, doi:10.1029/2005JG000150, 2006.

Romanovskii, N. N.: Erosion-thermokarst basins in the northern coastal lowlands of Yakutia and the New Siberian Islands, in: Permafrost Investigations, 1, Moscow State University, Moscow, 124-144, 1961 (in Russian).

Romanovskii, N. N., Hubberten, H.-W., Gavrilov, A. V., Tumskoy, V. E., Tipenko, G. S., Grigoriev, M. N., and Siegert, C.: Thermokarst and land-ocean interactions, Laptev Sea Region, Russia, Permafrost Periglac., 11, 137-152, 2000.

Romanovsky, V. E., Smith, S. L., and Christiansen, H. H.: Permafrost thermal state in the polar Northern Hemisphere during the International Polar Year 2007-2009: A synthesis, Permafrost Periglac., 21, 106-116, doi:10.1002/ppp.689, 2010.

Schirrmeister, L., Kunitsky, V. V., Grosse, G., Schwamborn, G., Andreev, A. A., Meyer, H., Kuznetsova, T., Bobrov, A., and Oezen, D.: Late Quaternary history of the accumulation plain north of the Chekanovsky Ridge (Lena Delta, Russia) - a multidisciplinary approach, Polar Geography, 27, 277-319, 2003.

Schirrmeister, L., Grosse, G., Schnelle, M., Fuchs, M., Krbetschek, M., Ulrich, M., Kunitsky, V., Grigoriev, M., Andreev, A., Kienast, F., Meyer, H., Babiy, O., Klimova, I., Bobrov, A., Wetterich, S., and Schwamborn, G.: Late Quaternary paleoenvironmental records from the western Lena Delta, Arctic Siberia, Palaeogeogr. Palaeocl., 299, 175-196, doi:10.1016/j.palaeo.2010.10.045, 2011a.

Schirrmeister, L., Kunitsky, V., Grosse, G., Wetterich, S., Meyer, H., Schwamborn, G., Babiy, O., Derevyagin, A., and Siegert, C.: Sedimentary characteristics and origin of the Late Pleistocene Ice Complex on north-east Siberian Arctic coastal lowlands and islands - A review, Quatern. Int., 241, 3-25, doi:10.1016/j.quaint.2010.04.004, 2011b.
Schneider, J., Grosse, G., and Wagner, D.: Land cover classification of tundra environments in the Arctic Lena Delta based on Landsat 7 ETM+ data and its application for upscaling of methane emissions, Remote Sens. Environ., 113, 380-391, doi:10.1016/j.rse.2008.10.013, 2009.

Schuur, E. A. G., Bockheim, J., Canadell, J. G., Euskirchen, E., Field, C. B., Goryachkin, S. V., Hagemann, S., Kuhry, P., Lafleur, P. M., Lee, H., Mazhitova, G., Nelson, F. E., Rinke, A., Romanovsky, V. E., Shiklomanov, N., Tarnocai, C., Venevsky, S., Vogel, J. G., and Zimov, S. A.: Vulnerability of permafrost carbon to climate change: Implications for the global carbon cycle, Bioscience, 58, 701-714, doi:10.1641/B580807, 2008.

Schuur, E., Vogel, J., Crummer, K., Lee, H., Sickman, J., and Osterkamp, T.: The effect of permafrost thaw on old carbon release and net carbon exchange from tundra, Nature, 459, 556-559, doi:10.1038/nature08031, 2009.

Schwamborn, G., Andreev, A. A., Rachold, V., Hubberten, H. W., Grigoriev, M. N., Tumskoy, V., Pavlova, E. Y., and Dorozhkina, M. V.: Evolution of Lake Nikolay, Arga Island, Western Lena River delta, during Late Pleistocene and Holocene time, Polarforschung, 70, 69-82, 2002a.

Schwamborn, G., Rachold, V., and Grigoriev, M. N.: Late Quaternary sedimentation history of the Lena Delta, Quatern. Int., 89, 119-134, 2002b.

Sher, A. V., Kaplina, T. N., and Ovander, M. G.: Unified regional stratigraphic chart for the Quaternary deposits in the YanaKolyma Lowland and its mountainous surroundings: Explanatory note in: Decisions of the Interdepartmental Stratigraphic Conference on the Quaternary of the Eastern USSR, Magadan, 1982, USSR Academy of Sciences, Far-Eastern Branch, NorthEastern Complex Research Institute, Magadan, 29-69, 1987 (in Russian).

Smith, L. C., Sheng, Y., MacDonald, G. M., and Hinzman, L. D.: Disappearing Arctic lakes, Science, 308, 1429, 2005.

Soloviev, P. A.: Cryolithozone of the northern part of the Lena and Amga interfluve, USSR Academy of Sciences, Moscow, 1959 (in Russian).

Soloviev, P. A.: Alas relief of Central Yakutia and its formation, in: Permafrost and accompanying phenomena on the territory of the Yakutian ASSR, USSR Academy of Sciences, Moscow, 38-53, 1962 (in Russian).

Star, J. and Estes, J.: Geographic Information Systems - an introduction, Prentice-Hall, Englewood Cliffs, New Jersey, 303 pp., 1990.

Strauss, J., Schirrmeister, L., Wetterich, S., Borchers, A., and Davydov, S.: Grain-size properties and organic-carbon stock of northeast Siberian Ice Complex (Yedoma) permafrost, Global Biogeochem. Cy., in review, 2011.

Ulrich, M., Morgenstern, A., Günther, F., Reiss, D., Bauch, K. E., Hauber, E., Rössler, S., and Schirrmeister, L.: Thermokarst in Siberian ice-rich permafrost: Comparison to asymmetric scalloped depressions on Mars, J. Geophys. Res., 115, E10009, doi:10.1029/2010JE003640, 2010.

van Everdingen, R. O. (Ed.): Multi-language glossary of permafrost and related ground-ice terms, National Snow and Ice Data Center/World Data Center for Glaciology, Boulder, available at: http://nsidc.org/fgdc/glossary, Rev. May 2005.

Veremeeva, A. and Gubin, S.: Modern tundra landscapes of the Kolyma Lowland and their evolution in the Holocene, Permafrost 
Periglac., 20, 399-406, doi:10.1002/ppp.674, 2009.

Walter, K. M., Zimov, S., Chanton, J. P., Verbyla, D., and Chapin III, F. S.: Methane bubbling from Siberian thaw lakes as a positive feedback to climate warming, Nature, 443, 71-75, doi:10.1038/nature05040, 2006.

Walter, K. M., Edwards, M. E., Grosse, G., Zimov, S., and Chapin III, F. S.: Thermokarst lakes as a source of atmospheric $\mathrm{CH}_{4}$ during the last deglaciation, Science, 318, 633-636, doi:10.1126/science.1142924, 2007.

West, J. J. and Plug, L. J.: Time-dependent morphology of thaw lakes and taliks in deep and shallow ground ice, J. Geophys. Res., 113, F01009, doi:10.1029/2006JF000696, 2008.

Wetterich, S., Kuzmina, S., Andreev, A. A., Kienast, F., Meyer, H., Schirrmeister, L., Kuznetsova, T., and Sierralta, M.: Palaeoenvironmental dynamics inferred from late Quaternary permafrost deposits on Kurungnakh Island, Lena Delta, Northeast Siberia, Russia, Quaternary Sci. Rev., 27, 1523-1540, doi:10.1016/j.quascirev.2008.04.007, 2008.

Wetterich, S., Schirrmeister, L., Andreev, A. A., Pudenz, M., Plessen, B., Meyer, H., and Kunitsky, V. V.: Eemian and Late Glacial/Holocene palaeoenvironmental records from permafrost sequences at the Dmitry Laptev Strait (NE Siberia, Russia), Palaeogeogr. Palaeocl., 279, 73-95, doi:10.1016/j.palaeo.2009.05.002, 2009.
Zimov, S. A., Voropaev, Y. V., Semiletov, I. P., Davidov, S. P., Prosiannikov, S. F., Chapin III, F. S., Chapin, M. C., Trumbore, S., and Tyler, S.: North Siberian lakes: A methane source fueled by Pleistocene carbon, Science, 277, 800-802, doi:10.1126/science.277.5327.800, 1997.

Zimov, S. A., Davydov, S. P., Zimova, G. M., Davydova, A. I., Schuur, E. A. G., Dutta, K., and Chapin III, F. S.: Permafrost carbon: Stock and decomposability of a globally significant carbon pool, Geophys. Res. L., 33, L20502, doi:10.1029/2006GL027484, 2006a.

Zimov, S. A., Schuur, E. A. G., and Chapin III, F. S.: Permafrost and the global carbon budget, Science 312, 1612-1613, doi:10.1126/science.1128908, 2006b.

Zona, D., Oechel, W. C., Kochendorfer, J., Paw U, K. T., Salyuk, A. N., Olivas, P. C., Oberbauer, S. F., and Lipson, D. A.: Methane fluxes during the initiation of a large-scale water table manipulation experiment in the Alaskan Arctic tundra, Global Biogeochem. Cy., 23, GB2013, doi:10.1029/2009GB003487, 2009. 